Prepared in cooperation with U.S. Fish and Wildlife Service

\title{
Baseline Channel Geometry and Aquatic Habitat Data for Selected Streams in the Matanuska-Susitna Valley, Alaska
}

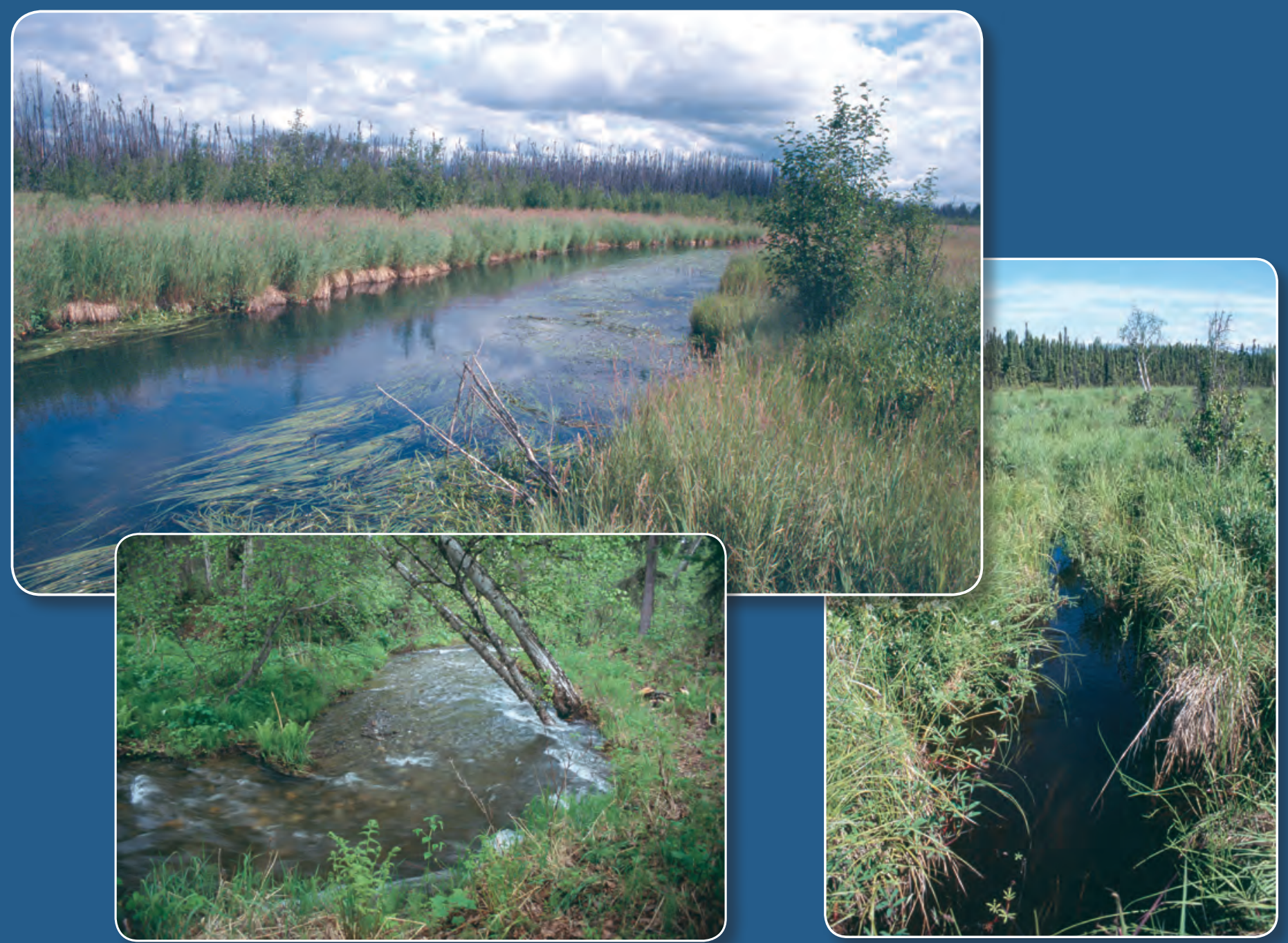

Scientific Investigations Report 2009-5084 
Cover: Photographs of study sites along Meadow Creek, an unnamed tributary to Little Meadow Creek, and Swiftwater Creek, a tributary to the Little Susitna River (clockwise from upper left), selected for the study as representative of a subset of streams in the Matanuska-Susitna Valley, Alaska. (Photographs taken by Janet Curran, U.S. Geological Survey, July 20, June 16, and May 23, 2005, respectively.) 


\section{Baseline Channel Geometry and Aquatic Habitat Data for Selected Streams in the Matanuska-Susitna Valley, Alaska}

By Janet H. Curran, U.S. Geological Survey; and

William J. Rice, U.S. Fish and Wildlife Service

Prepared in cooperation with U.S. Fish and Wildlife Service

Scientific Investigations Report 2009-5084 


\section{U.S. Department of the Interior \\ KEN SALAZAR, Secretary \\ U.S. Geological Survey \\ Suzette M. Kimball, Acting Director}

U.S. Geological Survey, Reston, Virginia: 2009

For more information on the USGS - the Federal source for science about the Earth, its natural and living resources, natural hazards, and the environment, visit http://www.usgs.gov or call 1-888-ASK-USGS

For an overview of USGS information products, including maps, imagery, and publications, visit http://www.usgs.gov/pubprod

To order this and other USGS information products, visit http://store.usgs.gov

Any use of trade, product, or firm names is for descriptive purposes only and does not imply endorsement by the U.S. Government.

Although this report is in the public domain, permission must be secured from the individual copyright owners to reproduce any copyrighted materials contained within this report.

Suggested citation:

Curran, J.H., and Rice, W.J., 2009, Baseline channel geometry and aquatic habitat data for selected streams in the Matanuska-Susitna Valley, Alaska: U.S. Geological Survey Scientific Investigations Report 2009-5084, 24 p. 


\section{Contents}

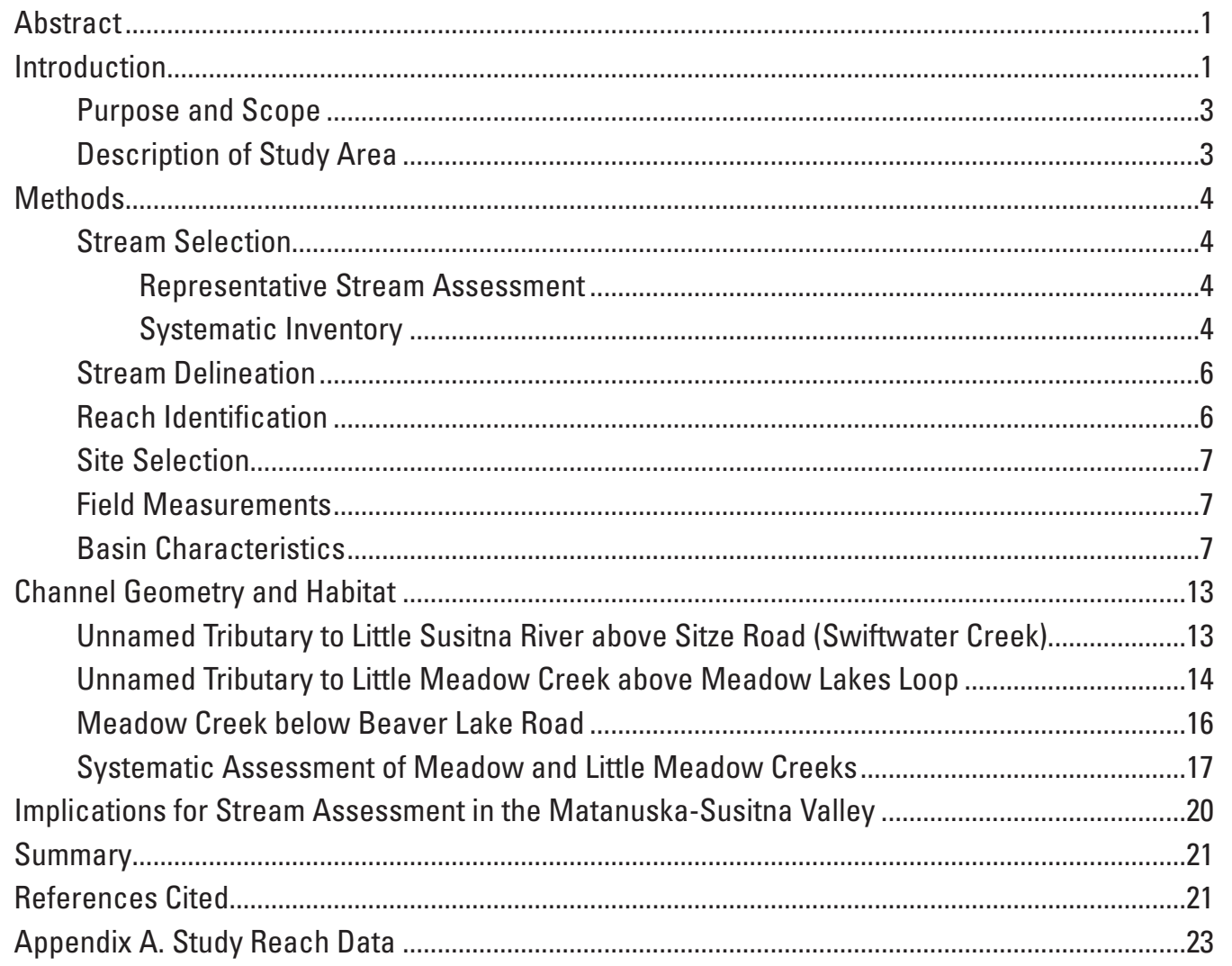




\section{Figures}

Figure 1. Map showing location of Matanuska-Susitna Valley and vicinity, Alaska....

Figure 2. Map showing study sites and drainage boundaries for selected representative streams in the Matanuska-Susitna Valley, Alaska....

Figure 3. Map showing streams delineated within the Big Lake, Alaska drainage, and streams for which channel geometry and habitat attributes were collected in 2005

Figure 4. Map showing locations of USGS continuously operating and crest-stage streamgages in the Matanuska-Susitna Valley

Figure 5. Photograph of study site on a tributary to Little Susitna River locally known as Swiftwater Creek, Alaska

Figure 6. Photograph showing study reach and survey points on unnamed tributary to Little Meadow Creek, Alaska

Figure 7. Photograph of study reach on unnamed tributary to Little Meadow Creek, Alaska

Figure 8. Map showing study site and survey points on Meadow Creek, Alaska ............ 15

Figure 9. Photograph showing study site on Meadow Creek, Alaska .................... 16

Figure 10. Graphs showing variation of bankfull channel width, width/depth ratio, and entrenchment ratio with distance along Meadow and Little Meadow Creeks, Alaska

Figure 11. Graph showing habitat types as a percent of wetted area for study reaches along Meadow and Little Meadow Creeks, Alaska

Figure 12. Graph showing dominant habitat cover type by percent of total length of stream assessed, Meadow and Little Meadow Creeks, Alaska

Figure 13. Map showing locations where spawning-sized gravel is present, or where some spawning gravel is present, along Meadow and Little Meadow Creeks, Alaska

Figure 14. Photographs showing examples of palustrine emergent, shrub-scrub, and forested wetlands associated with stream reaches along Meadow and Little Meadow Creeks, Alaska

\section{Tables}

Table 1. Methods for measuring reach geomorphology at study sites in the Matanuska-Susitna Valley, Alaska

Table 2. Methods for measuring reach habitat at study sites in the Matanuska-Susitna Valley, Alaska

Table 3. Basin characteristics for selected representative stream reaches in the Matanuska-Susitna Valley, Alaska

Table 4. Channel attributes for selected representative stream reaches in the Matanuska-Susitna Valley, Alaska

Table 5. Average channel attributes for Meadow Creek and Little Meadow Creek reaches, Alaska, weighted by reach length 


\section{Conversion Factors and Datums}

Inch/Pound to SI

\begin{tabular}{lcl}
\hline \multicolumn{1}{c}{ Multiply } & \multicolumn{1}{c}{ By } & \multicolumn{1}{c}{ To obtain } \\
\hline inch (in.) & Length & \\
inch (in.) & 2.54 & centimeter $(\mathrm{cm})$ \\
foot (ft) & 25.4 & millimeter $(\mathrm{mm})$ \\
mile (mi) & 0.3048 & meter $(\mathrm{m})$ \\
\hline & 1.609 & kilometer $(\mathrm{km})$ \\
\hline square foot $\left(\mathrm{ft}^{2}\right)$ & Area & \\
square foot $\left(\mathrm{ft}^{2}\right)$ & 929.0 & square centimeter $\left(\mathrm{cm}^{2}\right)$ \\
square mile $\left(\mathrm{mi}^{2}\right)$ & 0.09290 & square meter $\left(\mathrm{m}^{2}\right)$ \\
\hline & 2.590 & square kilometer $\left(\mathrm{km}^{2}\right)$ \\
\hline foot per second (ft/s) & Flow rate & \\
foot per minute (ft/min) & 0.3048 & meter per second $(\mathrm{m} / \mathrm{s})$ \\
cubic foot per second $\left(\mathrm{ft}^{3} / \mathrm{s}\right)$ & 0.3048 & meter per minute $(\mathrm{m} / \mathrm{min})$ \\
\hline
\end{tabular}

Temperature in degrees Fahrenheit $\left({ }^{\circ} \mathrm{F}\right)$ may be converted to degrees Celsius $\left({ }^{\circ} \mathrm{C}\right)$ as follows:

$$
{ }^{\circ} \mathrm{C}=\left({ }^{\circ} \mathrm{F}-32\right) / 1.8
$$

Datums

Vertical coordinate information is referenced to the North American Vertical Datum of 1929 (NAVD 29).

Horizontal coordinate information is referenced to the North American Datum of 1983 (NAD 83).

Altitude, as used in this report, refers to distance above the vertical datum.

Specific conductance is given in microsiemens per centimeter at 25 degrees Celsius $(\mu \mathrm{S} / \mathrm{cm}$ at $\left.25^{\circ} \mathrm{C}\right)$.

Concentrations of chemical constituents in water are given either in milligrams per liter (mg/L) or micrograms per liter $(\mu \mathrm{g} / \mathrm{L})$. 
This page intentionally left blank. 


\title{
Baseline Channel Geometry and Aquatic Habitat Data for Selected Streams in the Matanuska-Susitna Valley, Alaska
}

\author{
By Janet H. Curran, U.S. Geological Survey, and William J. Rice, U.S. Fish and Wildlife Service
}

\section{Abstract}

Small streams in the rapidly developing MatanuskaSusitna Valley in south-central Alaska are known to support anadromous and resident fish but little is known about their hydrologic and riparian conditions, or their sensitivity to the rapid development of the area or climate variability. To help address this need, channel geometry and aquatic habitat data were collected in 2005 as a baseline of stream conditions for selected streams. Three streams were selected as representative of various stream types, and one drainage network, the Big Lake drainage basin, was selected for a systematic assessment. Streams in the Big Lake basin were drawn in a Geographic Information System (GIS), and 55 reaches along 16 miles of Meadow Creek and its primary tributary Little Meadow Creek were identified from orthoimagery and field observations on the basis of distinctive physical and habitat parameters, most commonly gradient, substrate, and vegetation. Data-collection methods for sites at the three representative reaches and the 55 systematically studied reaches consisted of a field survey of channel and flood-plain geometry and collection of 14 habitat attributes using published protocols or slight modifications. Width/depth and entrenchment ratios along the MeadowLittle Meadow Creek corridor were large and highly variable upstream of Parks Highway and lower and more consistent downstream of Parks Highway. Channel width was strongly correlated with distance, increasing downstream in a log-linear relation. Runs formed the most common habitat type, and instream vegetation dominated the habitat cover types, which collectively covered 53 percent of the channel. Gravel suitable for spawning covered isolated areas along Meadow Creek and about 29 percent of Little Meadow Creek. Broad wetlands were common along both streams. For a comprehensive assessment of small streams in the Mat-Su Valley, critical additional data needs include hydrologic, geologic and geomorphic, and biologic data, in particular the contribution of ground water and lakes to streamflow, water quality, flood plain connectivity, and surficial geology.

\section{Introduction}

The Matanuska-Susitna (Mat-Su) Valley is a rapidly developing rural and suburban lowland near the Matanuska and Susitna Rivers in south-central Alaska (fig. 1). The Mat-Su Valley contains a dense network of small streams actively used by anadromous and resident fish, many unmapped, yet collectively critical to the Cook Inlet fishery. Effectively managing the development of this naturally productive area requires an understanding of the role and sensitivity of these small streams, the foundation of which is identification of streams and wetlands and documentation of their natural geomorphic and habitat characteristics. These local baseline studies are needed to help guide urban development, protect and enhance wetlands and streams, and design restoration and fish passage projects.

Small streams are defined for this report as having drainage areas of less than $100 \mathrm{mi}^{2}$. Although coarse-scale digital geospatial hydrographic data have been compiled for the Mat-Su Valley as part of regional and statewide efforts (such as the National Hydrography Dataset, recently completed for most of Alaska), no systematic inventory of small streams in the Mat-Su Valley has been undertaken. Similarly, although site-specific information regarding stream geomorphology and habitat conditions is available as a result of selected projects by various agencies, no systemwide assessment has been compiled. Understanding how many streams are present, how they interchange sediment and water with adjacent lands, how their habitats are used by aquatic biota, and their sensitivity to change, is necessary for management agencies to evaluate proposed projects, or for groups to maximize restoration effectiveness. In the absence of a program to address this full scope of questions, this study is an initial step toward documenting and understanding Mat-Su Valley streams by establishing a framework for data collection and collecting data for selected streams and watersheds. 


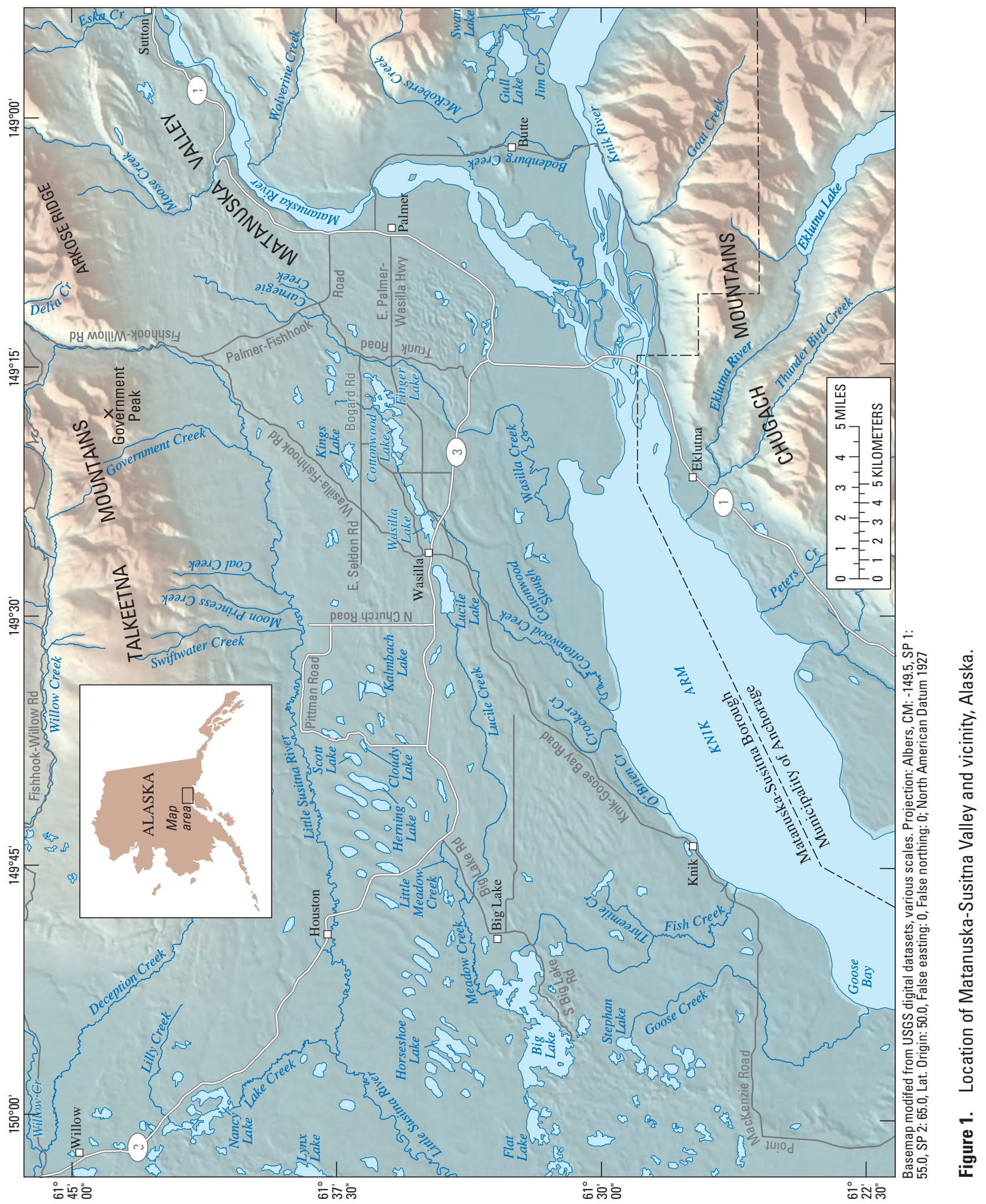


After recent watershed-planning, fish-passage design, and stream-restoration projects, the U.S. Fish and Wildlife Service (USFWS) expressed a need for updated information regarding small-stream geomorphology, hydrology, habitat, and fish use in the Mat-Su Valley. As an initial effort to promote systemwide understanding of small streams in the area, USFWS entered into a cooperative project with the U.S. Geological Survey (USGS) to establish a framework for collection, analysis, storage, and presentation of data that would enable evaluation of the critical geomorphic and hydrologic variables for small streams in the Mat-Su Valley. In this collaborative effort, the USGS and USFWS collected channel geometry and habitat data on selected stream reaches. A two-pronged data-collection program included documentation of three selected stream reaches and a systematic assessment of streams in a single stream network as an example of an effective strategy for assessing small streams in the Mat-Su Valley.

\section{Purpose and Scope}

This report summarizes the methods, results, and data needs from an initial study of geomorphic and habitat characteristics for a range of small streams in the Mat-Su Valley. Specific objectives were to form a strategy for long-term data collection and reporting, then collect data (1) strategically for small streams selected to be geomorphically representative of some of the types of streams in the Mat-Su Valley and (2) systematically for a suite of streams within a stream network.

This report does not present final analysis of which geomorphic and hydrologic variables are most critical for characterizing Mat-Su Valley area small streams, nor a comprehensive listing of stream reaches in the Meadow Creek stream network. It is expected that additional collection of hydrologic data will be required before this analysis can occur. Suggestions for strategic data collection to facilitate this analysis are included in the report.

\section{Description of Study Area}

The Mat-Su Valley encompasses the low-lying area between the Talkeetna and Chugach Mountains and the Susitna River and roughly forms two arms, one north-south arm along the Susitna River and an eastern arm along the Matanuska Valley. The study streams are in the valley bottom and side slopes of the eastern arm, an area of about $600 \mathrm{mi}^{2}$ bounded by the Little Susitna River to the west, the Talkeetna
Mountains to the north, the Chugach Mountains to the east, and Knik Arm of Cook Inlet to the south (fig. 1). This region is the most developed part of the Mat-Su Borough and includes the towns of Palmer and Wasilla, numerous communities, and rural areas. The U.S. Census Bureau shows the Borough population as 59,322 in 2000. Demographers estimate the rapidly growing population exceeded 74,000 by 2005 (Alaska Department of Commerce, Community, and Economic Development, 2005).

The study area is part of a northeast-trending structural trough with rocks of Mesozoic and Tertiary age overlain by Pleistocene glacial sediments. The complex tectonic history of this region produced a lithologically diverse suite of materials transported during glacial and alluvial processes, primarily the igneous and sedimentary rocks of the Talkeetna Mountains and the metasedimentary and mélange-like accretionary rocks of the Chugach Mountains (Barnes, 1962; Winkler, 1992; Reger and others, 1996). The seismically active Castle Mountain fault, which extends northeastward from the Susitna lowland along the southern edge of the Talkeetna Mountains, is the only fault in the study area to have disrupted Holocene sediments and might locally have influenced the course of the Little Susitna River (Haeussler, 1998).

Pleistocene glaciation by the Matanuska Glacier, presently 50 mi east of Palmer, and the Knik Glacier, 25 mi southeast of Palmer, blanketed the study area with till, morainal, and outwash deposits in sequences up to a few hundred feet thick (Trainer, 1960; Freethey and Scully, 1980; Reger and Updike, 1983). Ice-contact and outwash deposits are common in the eastern and central parts of the study area, grading to ground moraine deposits in the western part. Surficial topography owing to glacial occupation includes eskers, drumlins, outwash channels, and rhythmic ridges thought to be transverse or Rogen moraines (Reger and Updike, 1983). Moraines mapped between Big Lake and the Sustina River outline the extents of the advances of the most recent, Naptowne glaciation (Reger and others, 1996).

Holocene alluvial deposits are present in major stream valleys, and aeolian deposits that thin away from the Matanuska River are draped across the study area (Trainer, 1961). Locally strong winds and active loess deposition are still common, especially along the Matanuska River. A large earthquake in 1964 resulted in a regional zone of subsidence ranging from 1 to $2 \mathrm{ft}$ in the study area (Plafker, 1969). Notable biological landscape modification in the study area includes damming by beavers and the development of extensive peatlands. Mean annual precipitation ranges from $40 \mathrm{in}$. or more in the mountains to $20 \mathrm{in}$. or less in lowland areas (Jones and Fahl, 1994). 


\section{Methods}

Examining streams representative of the range of stream types present and systematically assessing streams within a particular watershed required two different suites of sites but similar data-collection methods. Preparation for representative stream assessments involved a broad categorization of streams. Preparation for systematic stream assessments involved stream delineation. Data collection for both types of assessment included channel geometry and habitat surveys to provide a baseline for future work and a reference for comparison to other stream types.

\section{Stream Selection}

\section{Representative Stream Assessment}

An informal inventory of streams across the study area involved the inspection of topographic maps and of the National Hydrography Dataset, winter and summer reconnaissance in 2005, and USFWS knowledge of local fishpassage and stream-restoration projects. From this, streams were broadly categorized by their physiographic settings, geomorphology, hydrology, and size. As a preliminary investigation, this study does not attempt to refine criteria for this categorization, nor does it catalog all streams present.

Large streams in the area (Matanuska, Knik, and Little Susitna Rivers) are dominated by areas external to the study area. High-gradient streams draining the Talkeetna Mountain front are captured by the Little Susitna River, which parallels the mountain front and effectively prevents the development of an extensive lowland segment of those streams. In contrast, streams in the adjacent Big Lake and Cottonwood Creek drainages originate entirely within the glaciated valley bottom and commonly are fed by small lakes. Streams in this setting are likely to have strong hydrologic and morphologic influences from ground-water contributions, and wetland and flood-plain interactions. Wasilla and McRoberts Creeks are some of the few streams in the study area that form in a mountainous area and traverse through the lowland to marine waters.

Three streams selected from these rough groups of streams form the suite of representative streams assessed for this study (fig. 2). The first is a tributary to the Little Susitna River above Sitze Road (locally known as Swiftwater Creek), representing a small, high-gradient mountain stream hydrologically dominated by snowmelt. Swiftwater Creek was selected because little is known about the Little Susitna River tributaries originating from the Talkeetna Mountains, which quickly concentrate surface-water runoff and might be significant spawning and rearing habitat for anadromous fish. The second is an unnamed tributary that drains flow from Scott and Cloudy Lakes into Little Meadow Creek, representing a small, low-gradient peatland stream originating from small lakes and hydrologically dominated by ground water. The third is Meadow Creek, the primary tributary to Big Lake, representing a moderately sized, low-gradient peatland stream hydrologically dominated by ground water. The unnamed Little Meadow Creek tributary and Meadow Creek were selected because peatland and ground water dominated streams are prevalent in the study area and are not well studied. Other streams considered appropriate, but not chosen for inclusion in this initial study, include upper Wasilla Creek, Cottonwood Creek, Cottonwood Slough, and McRoberts Creek.

\section{Systematic Inventory}

Drainage basins in the study area were evaluated on the basis of their geographic distribution, relevance to local landmanagement and habitat-restoration activities, and inclusion with other studies. The Big Lake basin, which was identified by the Mat-Su Borough, and Federal and State agencies (Environmental Protection Agency, National Marine Fisheries Service, Alaska Department of Environmental Conservation, USFWS, and U.S. Army Corps of Engineers) as a drainage basin of concern due to rapid urban development, best fit these criteria. The stream system of Big Lake basin is largely ground water driven (Jokela and others, 1991; Hogan, 1995) and many streams flow through wetlands, which may be particularly sensitive to increased development. About 76 culverts, many of them potential barriers to fish passage, convey streamflow in the Big Lake drainage (U.S. Fish and Wildlife Service, 2004). Data are lacking for management agencies to address potential impacts of future development activities to existing fisheries and other aquatic organisms.

Meadow Creek, a primary inflow stream to Big Lake, is formed by two major tributaries, Little Meadow and Lucile Creeks (fig. 1). Together, Meadow Creek and its tributaries form an eastward-extending stream network that drains nearly the entire Big Lake basin. Meadow Creek, Little Meadow Creek, and selected tributaries to Little Meadow Creek were selected for systematic analysis, in part because habitatassessment data for Meadow and Little Meadow Creeks were identified as a data gap for fisheries management in Big Lake at a restoration committee meeting hosted by Alaska Department of Natural Resources in 2004 and by Alaska Department of Fish and Game at the Big Lake Watershed Forum in 2005 (Matanuska-Susitna Borough, 2005). In addition, these small, wetland streams are not well studied in geomorphic literature, so baseline-data collection and analysis are important contributions. 


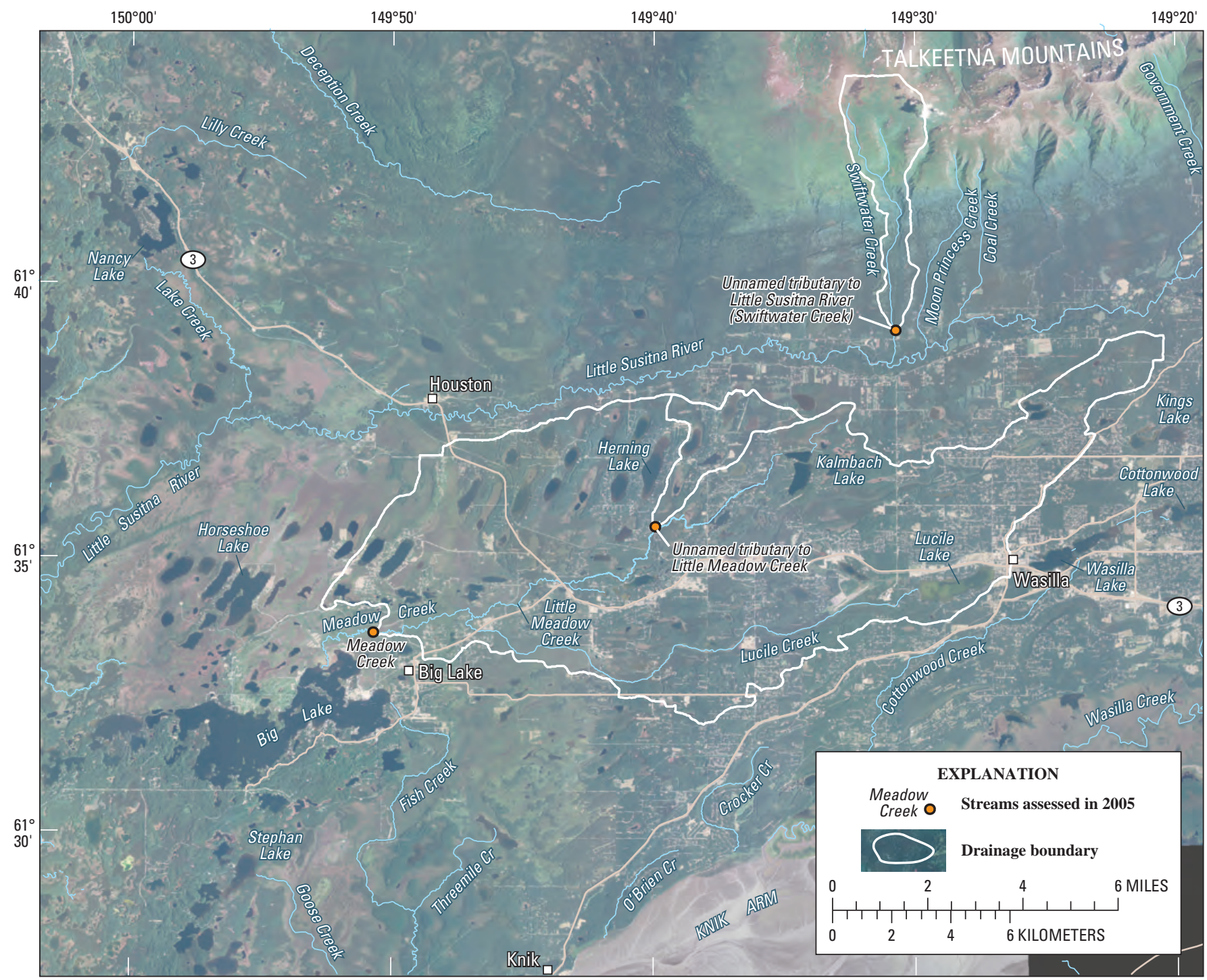

Imagery: USDA-NRCS orthophoto, 1-meter pixels, 2004 photography. Basemap modifed from USGS digital datasets, various scales. Projection: Albers, CM: -149.5, SP 1: 55.0, SP 2: 65.0, Lat. Origin: 50.0, False easting: 0, False northing: 0; North American Datum 1927

Figure 2. Study sites and drainage boundaries for selected representative streams in the Matanuska-Susitna Valley, Alaska.

The studied streams included Meadow Creek from its mouth at Big Lake to its end at the confluence of Little Meadow and Lucile Creeks, a distance of about $6.4 \mathrm{mi}$, and Little Meadow Creek from the same confluence upstream past Pittman Road and Rainbow Lake to a manmade earthen dam at the outlet of an unnamed lake downstream from Beverly
Lake. The studied distance along Little Meadow Creek is about $10 \mathrm{mi}$, including $0.6 \mathrm{mi}$ through lakes. Studied stream reaches make up an estimated 91 percent of the stream length of Little Meadow Creek. Lakes make up about $1.8 \mathrm{mi}$ of the total length of Little Meadow Creek. Selected reaches along tributaries to Little Meadow Creek also were studied. 


\section{Stream Delineation}

To begin the systematic assessment, all streams in the Big Lake drainage discernible from available data were delineated by USFWS in a Geographic Information System (GIS; fig. 3 ). Data sources included USGS 1:63,360 scale topographic maps, a recreational map (Barnes, 1997), culvert surveys (U.S. Fish and Wildlife Service, 2004), 2004-05 orthophotographs

(U.S. Department of Agriculture Natural Resources Conservation Service, 2005), and observations during site visits. Delineation consisted of on-screen digitizing of lines following all stream courses visible in orthophotographs, or known from maps or field observations. This study delineated $106 \mathrm{mi}$ of stream centerlines, representing the most comprehensive stream delineation currently available in the Big Lake drainage. The stream centerlines are available as a shapefile available at http://pubs.usgs.gov/sir/2009/5084/.

\section{Reach Identification}

Reaches, or lengths of stream having similar geomorphic characteristics, were identified using USGS protocols (Fitzpatrick and others, 1998). Appendix A and the shapefile available at http://pubs.usgs.gov/sir/2009/5084/ present the reaches and their characteristics. The most common

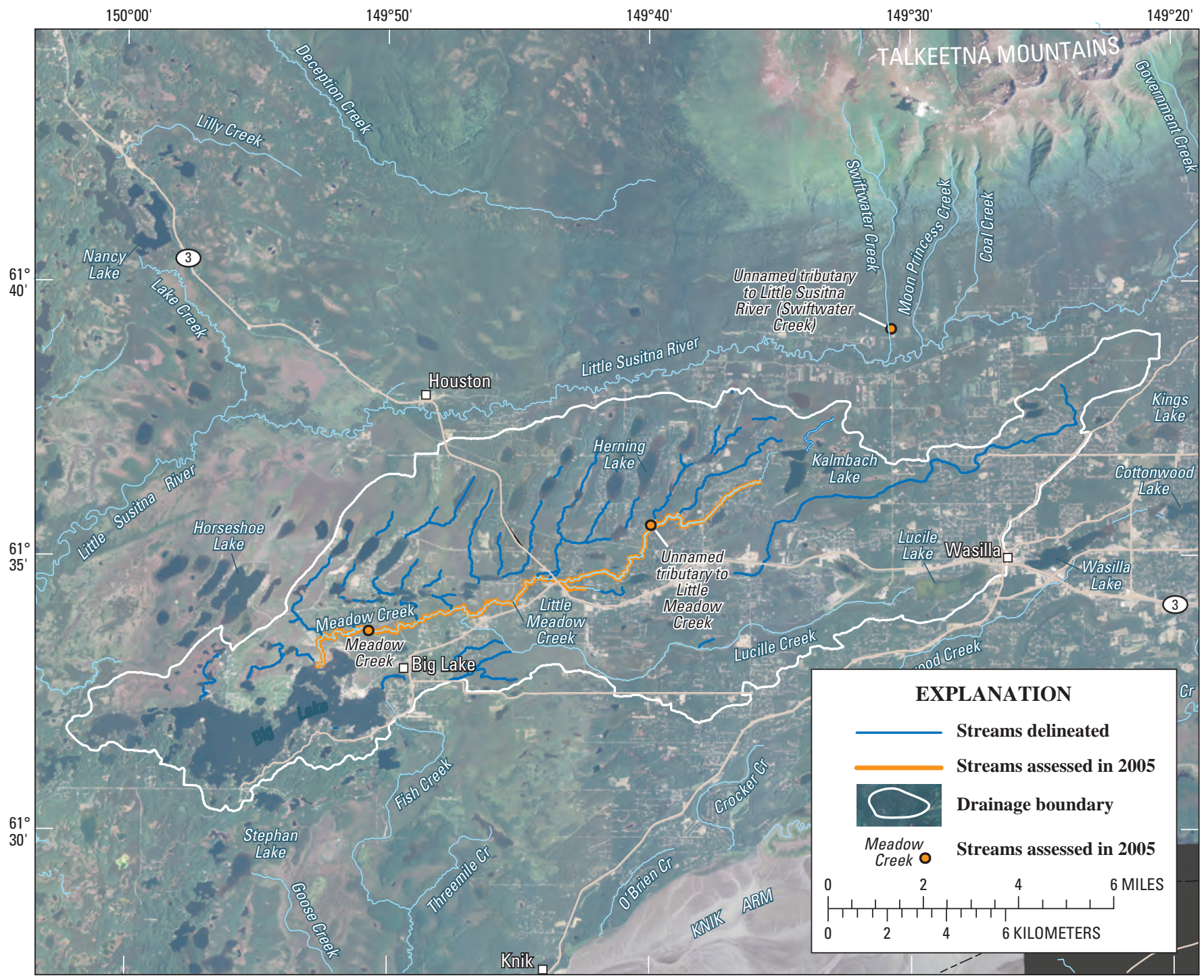

Imagery: USDA-NRCS orthophoto, 1-meter pixels, 2004 photography. Basemap modifed from USGS digital datasets, various scales. Projection: Albers, CM: -149.5, SP 1: 55.0, SP 2: 65.0, Lat. Origin: 50.0,

False easting: 0, False northing: 0; North American Datum 1927

Figure 3. Streams delineated within the Big Lake, Alaska drainage, and streams for which channel geometry and habitat attributes were collected in 2005. 
distinguishing feature was a combination of stream gradient, substrate, and vegetation. Reach boundaries initially were drawn from orthophotographs, maps, and field observations from previous work, then refined during field-data collection.

The reach identification code consists of a two- or three-letter stream code for a named stream, followed by as many two-digit groups of tributary identifiers as necessary, then followed by a two-digit reach identifier. Tributaries are identified in upstream order, with even values on the right (as viewed facing downstream) and odd numbers on the left. The latitude and longitude of the downstream-most endpoint of the reach, as determined in the GIS, was assigned to the systematic inventory reaches. A field-obtained, site-specific geographic coordinate was assigned to the representative reaches.

Fifty-five reaches were identified along the streams in the Meadow Creek drainage selected for the systematic inventory. Reach boundaries are shown in the shapefile (available at http://pubs.usgs.gov/sir/2009/5084/) of streams drawn for the Big Lake drainage.

For the representative stream assessment, only one reach was identified along each of the three selected streams. These reaches were selected as potential references for restoration projects, and to be considered for longer term monitoring efforts. Highest priority was given to reaches with undisturbed bed and banks, with no history of channel relocation, and with relatively undeveloped watersheds such that the streamflow regime (especially the magnitude, frequency, and timing of floods) likely was similar to predevelopment conditions. Preference was given to reaches near an existing, historical, or potential streamgage (fig. 4). Data to support reach selection included local knowledge of stream relocations for roadway construction, field observation of potential site conditions and proximity to infrastructure, and observations of urban development patterns on 2004/2005 orthophotos by the U.S. Department of Agriculture Natural Resources Service (2005).

Swiftwater Creek and the unnamed tributary to Little Meadow Creek are relatively undisturbed and in watersheds with little urban development. Meadow Creek is in a moderately developed watershed, but the selected reach has undisturbed bed and banks and is about $0.5 \mathrm{mi}$ downstream of the nearest road crossing.

\section{Site Selection}

Within each reach, a site for geometry and habitat assessments was selected. Physical attributes such as gradient, substrate, and vegetation generally remained constant throughout each reach such that the selection of a random or arbitrary survey site within the reach adequately characterized the reach.
The habitat survey was performed on a length of stream at least 20 bankfull channel widths long. Within shorter reaches, the entire reach was considered the site for the purposes of the habitat survey. A typical site was 200 to $300 \mathrm{ft}$ long. Specific locations were randomly selected, except where obvious local alterations such as road crossings affected the stream.

\section{Field Measurements}

Field measurements by USFWS and USGS consisted of a survey of channel geometry and measurement or estimation of habitat attributes. Table 1 identifies the channel attributes surveyed, their descriptions, the original published protocol for data collection procedures, and any modifications made for the purposes of this project. For each of the three representative sites, latitude and longitude was obtained with a Garmin eTrex ${ }^{\circledR}$ global positioning system (GPS) with horizontal accuracy generally within $15 \mathrm{ft}$.

Two cross sections and a longitudinal profile were measured at each selected site. No monuments were placed in part because of ground instability at peatland sites and in part because repeated surveys were not part of the study design. The cross sections were selected to include one riffle (or run, if riffles not present) and one pool (or run, if pools not present). Cross-section-based channel geometry and habitat data were collected at the riffle section. At Swiftwater Creek and at all sites within the systematic inventory, elevations were surveyed with a laser level and surveyor's staff and distances were measured with a fiberglass tape. Conventional surveying was accomplished at the Little Meadow Creek tributary and Meadow Creek sites using a Wild T1600 total station and a Trimble TSC1 datalogger.

Habitat data were collected in general accordance with published protocols (Johnston and Slaney, 1996; Fitzpatrick and others, 1998). Table 2 identifies the habitat attributes surveyed, their descriptions, the original published protocol, and any modifications to the protocol made for the purposes of this project.

\section{Basin Characteristics}

Surface-water drainage boundaries (ig. 2) were drawn for the three selected sites by hand drawing each basin's topographic divide from contour lines on USGS topographic maps. Each boundary was digitized, then refined manually in a GIS with an overlay of a 2004-05 orthophotograph by the U.S. Department of Agriculture Natural Resources Conservation Service (2005). Selected basin characteristics (table 3) were obtained for the sites in accordance with Curran and others (2003). These basin characteristicsdrainage area, area of lakes and ponds, and mean annual precipitation - provide basic descriptions of the sites and also are the variables required for input to regional flood-frequency estimation equations (Curran and others, 2003). 


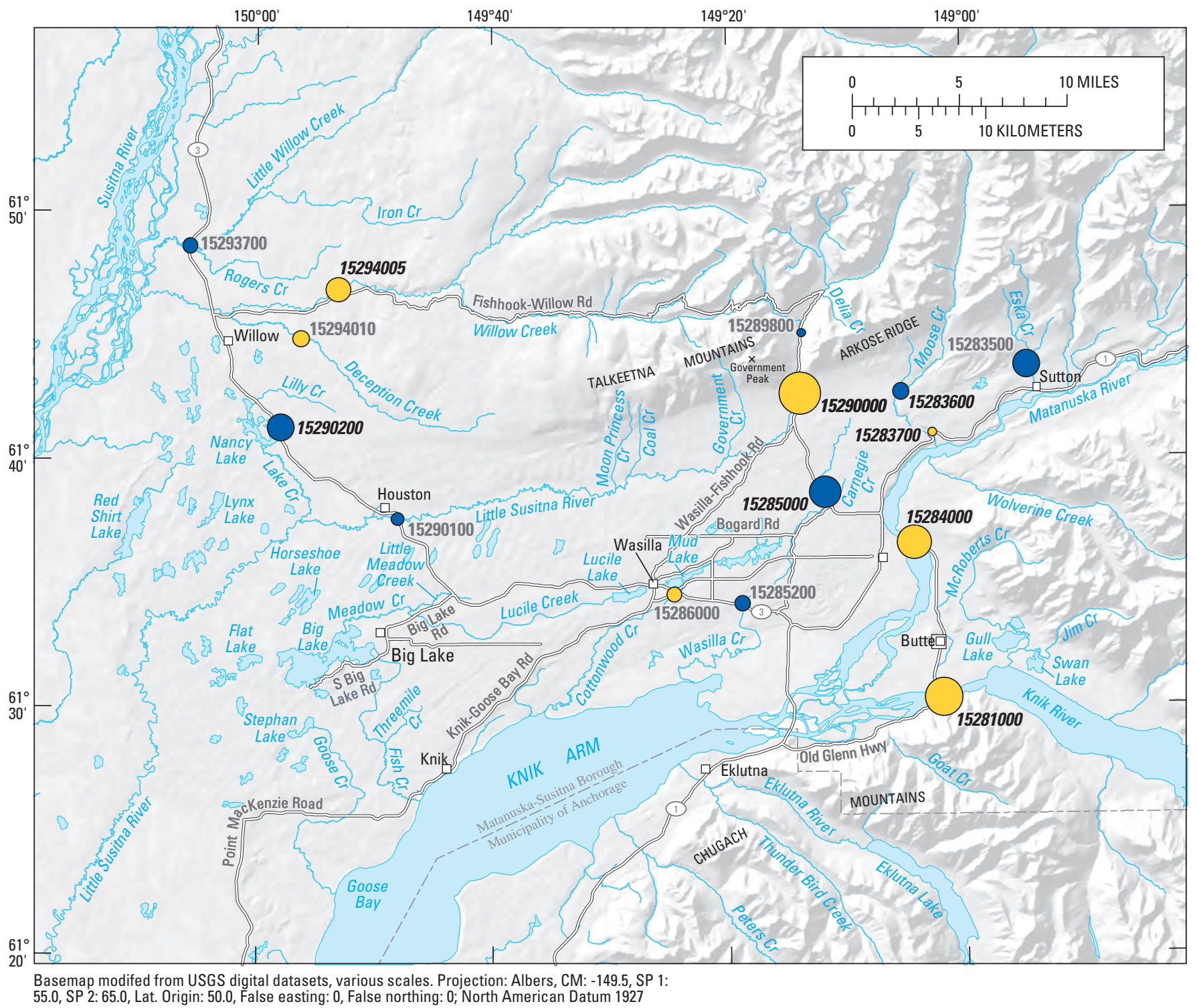

Basemap modifed from USGS digital datasets, various scales. Projection: Albers, CM: -149.5, SP
55.0, SP 2: 65.0, Lat. Origin: 50.0, False easting: 0, False northing: 0; North American Datum 1927

EXPLANATION

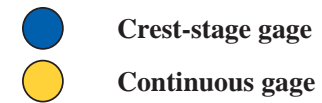

15285000 Gage active in 2008

15285200 Gage inactive in 2008

Number of peaks in record

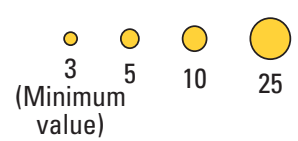

Streamgage

ID
Streamgage nam

ik R Nr Palmer, AK

Eska C Nr Sutton, AK

Premier C Nr Sutton, AK

Moose C Nr Palmer, AK

Matanuska R At Palmer, AK

Wasilla C Nr Palmer, AK

Wasilla C Nr Wasilla, AK

Cottonwood C Nr Wasilla, AK

Fishhook C Nr Palmer, AK

L Susitna R Nr Palmer, AK

L Susitna R Nr Houston, AK

Nancy Lk Tr Nr Willow, AK

L Willow C Nr Kashwitna, AK

Willow C Nr Willow, AK

Deception C Nr Willow, AK
Number of peaks in record

15290200

15293700

15294005

15294010

49
25
9
3
37
32
8
8
3
58
6
24
7
22
8

Figure 4. Locations of USGS continuously operating and crest-stage streamgages in the Matanuska-Susitna Valley. 
Table 1. Methods for measuring reach geomorphology at study sites in the Matanuska-Susitna Valley, Alaska.

[NA, not applicable; USGS, U.S. Geological Survey]

\begin{tabular}{|c|c|c|c|c|}
\hline Attribute & Description & Categories & $\begin{array}{c}\text { Basis for measurement } \\
\text { protocol }\end{array}$ & $\begin{array}{l}\text { Details of, or modifications to, } \\
\text { measurement protocol }\end{array}$ \\
\hline Stream name & $\begin{array}{l}\text { U.S. Board on Geographic } \\
\text { Names designated stream } \\
\text { name }\end{array}$ & NA & $\begin{array}{l}\text { Appearance in Geographic } \\
\text { Names Information System } \\
\text { (GNIS) }\end{array}$ & $\begin{array}{l}\text { None, designated NA if no official } \\
\text { name. }\end{array}$ \\
\hline Watershed & $\begin{array}{l}\text { USGS designated watershed } \\
\text { name }\end{array}$ & NA & $\begin{array}{l}\text { USGS official designation at } \\
\text { 6th level Hydrologic Unit } \\
\text { Code }\end{array}$ & None. \\
\hline Study type & $\begin{array}{l}\text { Reach was part of the } \\
\text { representative stream } \\
\text { assessment or systematic- } \\
\text { stream network assessment }\end{array}$ & $\begin{array}{l}\text { Representative, } \\
\text { stream network }\end{array}$ & This report & $\begin{array}{l}\text { No measurement protocol for this } \\
\text { attribute. }\end{array}$ \\
\hline Reach length & $\begin{array}{l}\text { Estimated length at least } 20 \\
\text { times average stream width } \\
\text { and consistent geomorphic } \\
\text { features }\end{array}$ & NA & Fitzpatrick and others, 1998 & $\begin{array}{l}\text { Length estimated from } \\
\text { orthophotograph determination of } \\
\text { consistent geomorphic features and } \\
\text { field verified. }\end{array}$ \\
\hline $\begin{array}{l}\text { Profile } \\
\quad \text { qualifier }\end{array}$ & $\begin{array}{l}\text { Dominant substrate or debris } \\
\text { present in association with } \\
\text { profile type }\end{array}$ & $\begin{array}{l}\text { (r) bedrock, } \\
\text { (b) boulder, } \\
\text { (c) cobble, } \\
\text { (g) gravel, } \\
\text { (s) sand, } \\
\text { (z) silt, } \\
\text { (w) wood, } \\
\text { (u) unknown }\end{array}$ & Wheaton, 2003 & No modifications made. \\
\hline $\begin{array}{l}\text { Maximum } \\
\text { bankfull depth }\end{array}$ & $\begin{array}{l}\text { Maximum difference in } \\
\text { elevation between thalweg } \\
\text { streambed surface and } \\
\text { bankfull stage estimate }\end{array}$ & NA & $\begin{array}{l}\text { Rosgen, 1996; } \\
\text { Fitzpatrick and others, } 1998\end{array}$ & $\begin{array}{l}\text { An estimate of the active channel } \\
\text { width was used as a surrogate for } \\
\text { bankfull in wetland environments. } \\
\text { For nonwetland environments, } \\
\text { the State's legal definition of } \\
\text { ordinary high water was used. } \\
\text { One representative riffle (or run, if } \\
\text { riffle did not exist) was randomly } \\
\text { selected and measured. }\end{array}$ \\
\hline $\begin{array}{l}\text { Mean } \\
\text { bankfull depth }\end{array}$ & $\begin{array}{l}\text { Mean difference in elevation } \\
\text { between thalweg streambed } \\
\text { surface and bankfull stage } \\
\text { estimate }\end{array}$ & NA & $\begin{array}{l}\text { Rosgen, 1996; } \\
\text { Fitzpatrick and others, } 1998\end{array}$ & Same as for Maximum bankfull depth. \\
\hline
\end{tabular}


Table 1. Description of methods for measuring channel attributes at study sites in the Matanuska-Susitna Valley, Alaska.—Continued

[NA, not applicable; USGS, U.S. Geological Survey]

\begin{tabular}{|c|c|c|c|c|}
\hline Attribute & Description & Categories & $\begin{array}{c}\text { Basis for measurement } \\
\text { protocol }\end{array}$ & $\begin{array}{l}\text { Details of, or modifications to, } \\
\text { measurement protocol }\end{array}$ \\
\hline $\begin{array}{l}\text { Bankfull } \\
\text { width }\end{array}$ & $\begin{array}{l}\text { Bank to bank width of a stream } \\
\text { channel measured at the } \\
\text { elevation of bankfull stage }\end{array}$ & NA & $\begin{array}{l}\text { Rosgen, 1996; } \\
\text { Fitzpatrick and others, } 1998\end{array}$ & Same as for Maximum bankfull depth. \\
\hline Width/depth ratio & $\begin{array}{l}\text { Ratio of bankfull width to mean } \\
\text { bankfull depth }\end{array}$ & NA & $\begin{array}{l}\text { Rosgen, 1996; } \\
\text { Fitzpatrick and others, } 1998\end{array}$ & No modifications made. \\
\hline Entrenchment & $\begin{array}{l}\text { Ratio of flood-prone width to } \\
\text { bankfull width }\end{array}$ & NA & Rosgen, 1996 & No modifications made. \\
\hline Bed material & $\begin{array}{l}\text { Sediment present in } \\
\text { representative riffle (or run) } \\
\text { on the streambed at time of } \\
\text { survey }\end{array}$ & $\begin{array}{l}\text { (1) clay/silt, } \\
\text { (2) silt/sand, } \\
\text { (3) sand/gravel, } \\
\text { (4) gravel/cobble, } \\
\text { (5) cobble/boulder, } \\
\text { (6) peat/root, } \\
\text { (7) bedrock }\end{array}$ & Wheaton, 2003 & $\begin{array}{l}\text { Modified with } \\
\text { (3.5) sand/cobble, } \\
\text { (4.5) gravel/boulder. } \\
\text { Pebble count if primarily cobble } \\
\text { or gravel. Visual observation if } \\
\text { primarily sand and silt. }\end{array}$ \\
\hline Bank material & $\begin{array}{l}\text { Predominant material exposed } \\
\text { on the streambank between } \\
\text { the streambed and bankfull } \\
\text { stage }\end{array}$ & Same as for Bed Material & Wheaton, 2003 & Same as for Bed Material \\
\hline Lake reach & $\begin{array}{l}\text { Routing reach is or is not } \\
\text { through lake }\end{array}$ & $\begin{array}{l}\text { (Yes) lake reach; } \\
\text { (No) not lake reach }\end{array}$ & Wheaton, 2003 & $\begin{array}{l}\text { No modifications on lake or stream } \\
\text { definitions. }\end{array}$ \\
\hline
\end{tabular}


Table 2. Methods for measuring reach habitat at study sites in the Matanuska-Susitna Valley, Alaska.

[NA, not applicable; <, less than; >, greater than; mm, millimeter; cm, centimeter; m, meter; \%, percent]

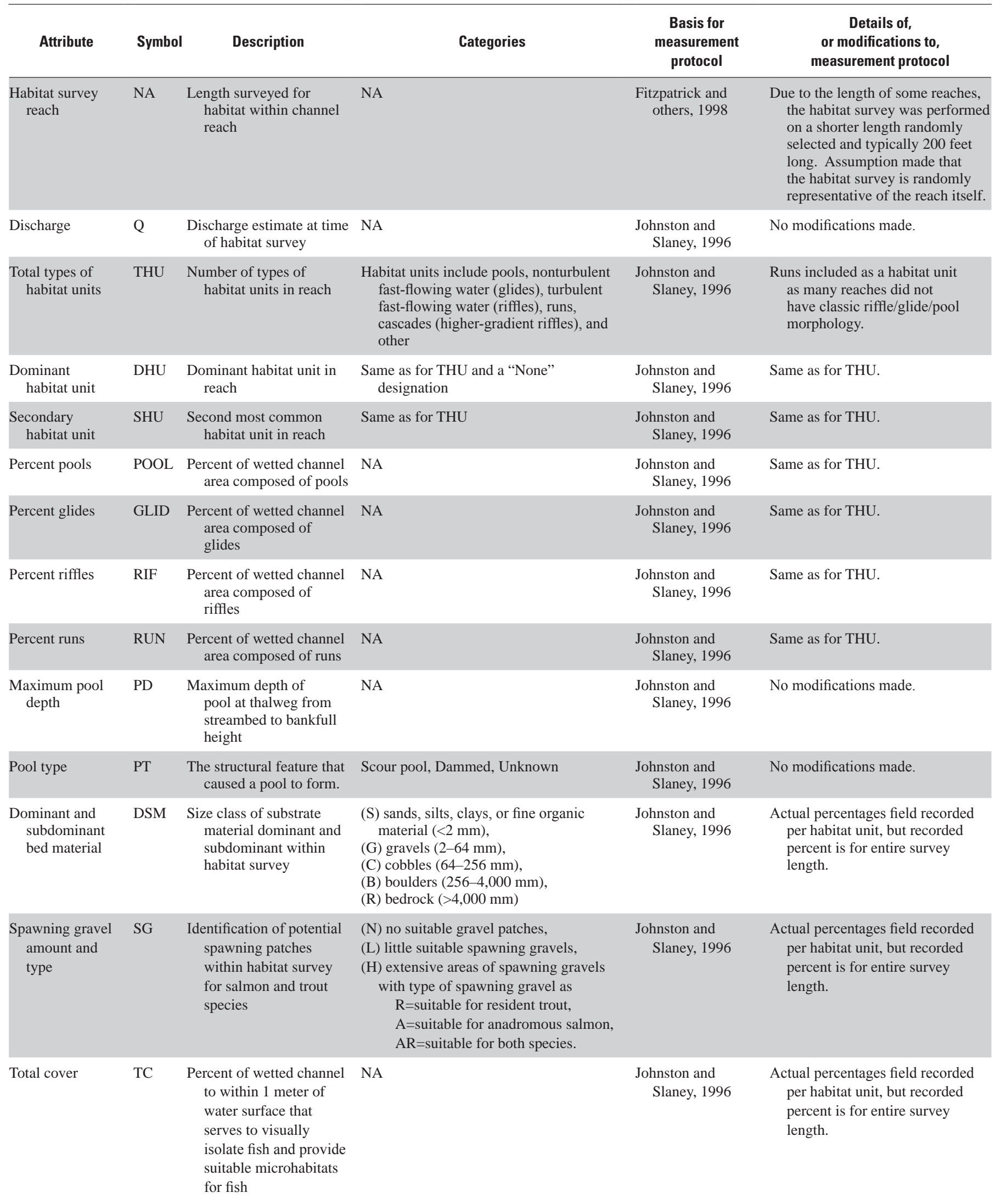


Table 2. Methods for measuring habitat attributes at study sites in the Matanuska-Susitna Valley, Alaska.—Continued

[NA, not applicable; <, less than; >, greater than; mm, millimeter; cm, centimeter; m, meter; \%, percent]

\begin{tabular}{|c|c|c|c|c|c|}
\hline Attribute & Symbol & Description & Categories & $\begin{array}{l}\text { Basis for } \\
\text { measurement } \\
\text { protocol }\end{array}$ & $\begin{array}{l}\text { Details of, } \\
\text { or modifications to, } \\
\text { measurement protocol }\end{array}$ \\
\hline $\begin{array}{l}\text { Off channel } \\
\text { habitat }\end{array}$ & $\mathrm{OCH}$ & $\begin{array}{l}\text { Side channels that may be } \\
\text { used by fish as refuges } \\
\text { or rearing areas at high } \\
\text { flows }\end{array}$ & $\begin{array}{l}\text { (SC) side channels, } \\
\text { (SL) sloughs (blind-ended channels), } \\
\text { (PD) off-channel ponds, } \\
\text { (WL) seasonally flooded wetlands / N=no } \\
\text { access to fish, } \\
\mathrm{P}=\text { accessible only at high flows, } \\
\mathrm{G}=\text { accessible at most flows / total length }\end{array}$ & $\begin{array}{l}\text { Johnston and } \\
\text { Slaney, } 1996\end{array}$ & No modifications made. \\
\hline $\begin{array}{l}\text { Riparian } \\
\text { vegetation } \\
\text { type }\end{array}$ & RVT & $\begin{array}{l}\text { Type and structural } \\
\text { stage of the dominant } \\
\text { vegetation of adjacent } \\
\text { riparian area }\end{array}$ & $\begin{array}{l}\mathrm{S}=\text { shrub/herb, } \\
\mathrm{D}=\text { Deciduous forest, } \\
\mathrm{M}=\text { Mixed conifer/deciduous forest }\end{array}$ & $\begin{array}{l}\text { Johnston and } \\
\text { Slaney, } 1996\end{array}$ & $\begin{array}{l}\text { Simplified to denote major } \\
\text { categories only. }\end{array}$ \\
\hline
\end{tabular}


Table 3. Basin characteristics for selected representative stream reaches in the Matanuska-Susitna Valley, Alaska.

[mi² , square miles; in., inches]

\begin{tabular}{llllc}
\hline \multicolumn{1}{c}{ Stream } & Reach & $\begin{array}{c}\text { Drainage } \\
\text { area } \\
\left(\mathbf{m i}^{2}\right)\end{array}$ & $\begin{array}{c}\text { Mean annual } \\
\text { precipitation } \\
\text { (in.) }\end{array}$ & $\begin{array}{c}\text { Area of lakes } \\
\text { and ponds } \\
\text { (percent of } \\
\text { drainage area) }\end{array}$ \\
\hline $\begin{array}{l}\text { Unnamed tributary to Little } \\
\text { Susitna River (Swiftwater }\end{array}$ & SW-00-02 & 5.03 & 25 & 0 \\
$\begin{array}{l}\text { Creek) } \\
\text { Unnamed tributary to Little } \\
\text { Meadow Creek }\end{array}$ & LM-60-00-01 & 3.32 & 20 & 12 \\
Meadow Creek & MDO-00-04 & 70.0 & 20 & 7 \\
\hline
\end{tabular}

\section{Channel Geometry and Habitat}

\section{Unnamed Tributary to Little Susitna River above Sitze Road (Swiftwater Creek)}

Swiftwater Creek occupies one of several linear, rhythmic ridge-swale features perpendicular to the front of the Talkeetna Mountains. These features may be of glacial origin but their specific genesis has not yet been explained (Sarah Kopczynski, Lehigh University, oral commun., 2006). Swiftwater Creek's drainage area extends up a small, steep valley to the summit of unnamed peaks in the Talkeetna Mountains (fig. 2). The study site is in a transitional area where the stream emerges from a confined valley and flows onto a gentle slope paralleling the Little Susitna River. Channel geometry and habitat attributes for this reach, SW-00-02, are discussed below and presented in detail in appendix A.

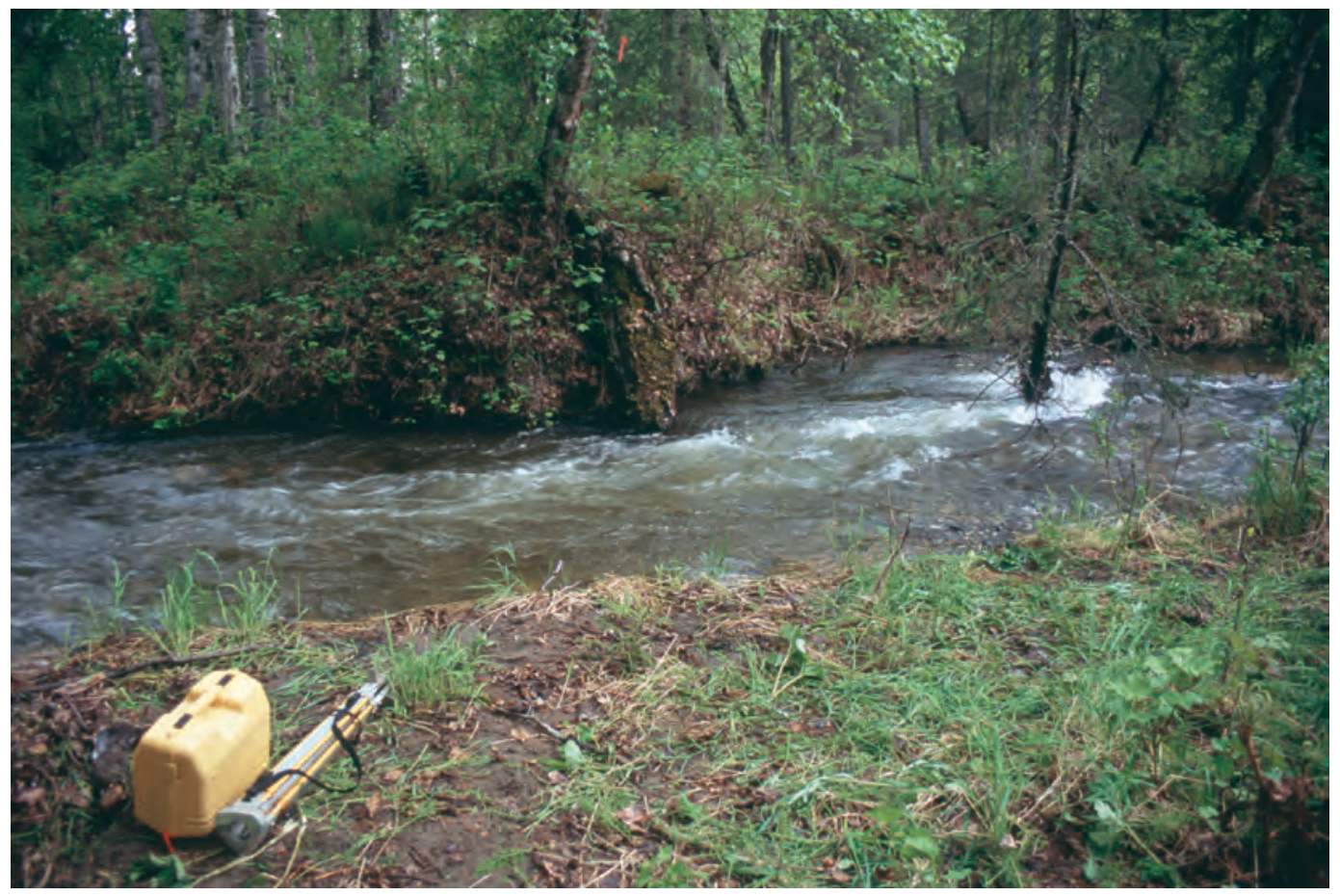

Figure 5. Study site on a tributary to Little Susitna River locally known as Swiftwater Creek, Alaska (reach ID SW-00-02). 
Table 4. Channel attributes for selected representative stream reaches in the Matanuska-Susitna Valley, Alaska.

[Width/depth ratio and E ntrenchment ratio: Ratios were computed prior to rounding and may not match the result obtained by dividing other, rounded values in this table. $\mathrm{ft}$, feet]

\begin{tabular}{lcccccc}
\hline \multicolumn{1}{c}{ Stream } & Reach & $\begin{array}{c}\text { Bankfull } \\
\text { depth (ft) }\end{array}$ & $\begin{array}{c}\text { Bankfull } \\
\text { width (ft) }\end{array}$ & $\begin{array}{c}\text { Width/depth Entrenchment } \\
\text { ratio }\end{array}$ & $\begin{array}{c}\text { Sinuosity } \\
\text { ratio }\end{array}$ & Slope \\
\hline $\begin{array}{l}\text { Unnamed tributary to Little Susitna River } \\
\text { (Swiftwater Creek) }\end{array}$ & SW-00-02 & 1.8 & 29 & 16 & 6.8 & 1.2 \\
$\begin{array}{l}\text { Unnamed tributary to Little Meadow Creek LM-60-00-01 } \\
\text { Meadow Creek }\end{array}$ & 1.6 & 5.0 & 3.1 & 48 & 1.4 \\
\hline
\end{tabular}

H abitat.- - Habitat in this tributary to the Little Susitna River is typical of many of the small streams draining the Talkeetna Mountains. The reach is a pool-riffle-glide system, with less than 2 percent total coverage of habitat cover types, which consist primarily of undercut banks and secondarily of overhanging vegetation. Off-channel habitat and pools were present, and spawning gravels extended throughout the reach. The bed was composed of cobble and gravel, and banks were cobble and gravel topped with silt. Total canopy cover was about 20 percent, consisting of a mature coniferous and deciduous forest.

\section{Unnamed Tributary to Little Meadow Creek above Meadow Lakes Loop}

This tributary to Little Meadow Creek drains Scott and Cloudy Lakes within the Big Lake drainage, which is a lowland drainage with no steep-gradient headwaters. The headwaters of the Big Lake drainage are composed of numerous small streams, lakes, and wetlands likely maintained by a high, stable regional ground-water table. Many of the low gradient reaches of small streams in the Big Lake drainage flow through filled lake basins or beaver-dammed areas. The study site on the unnamed tributary to Little Meadow Creek is about $800 \mathrm{ft}$ upstream of Meadow Lakes Loop (fig. 6).

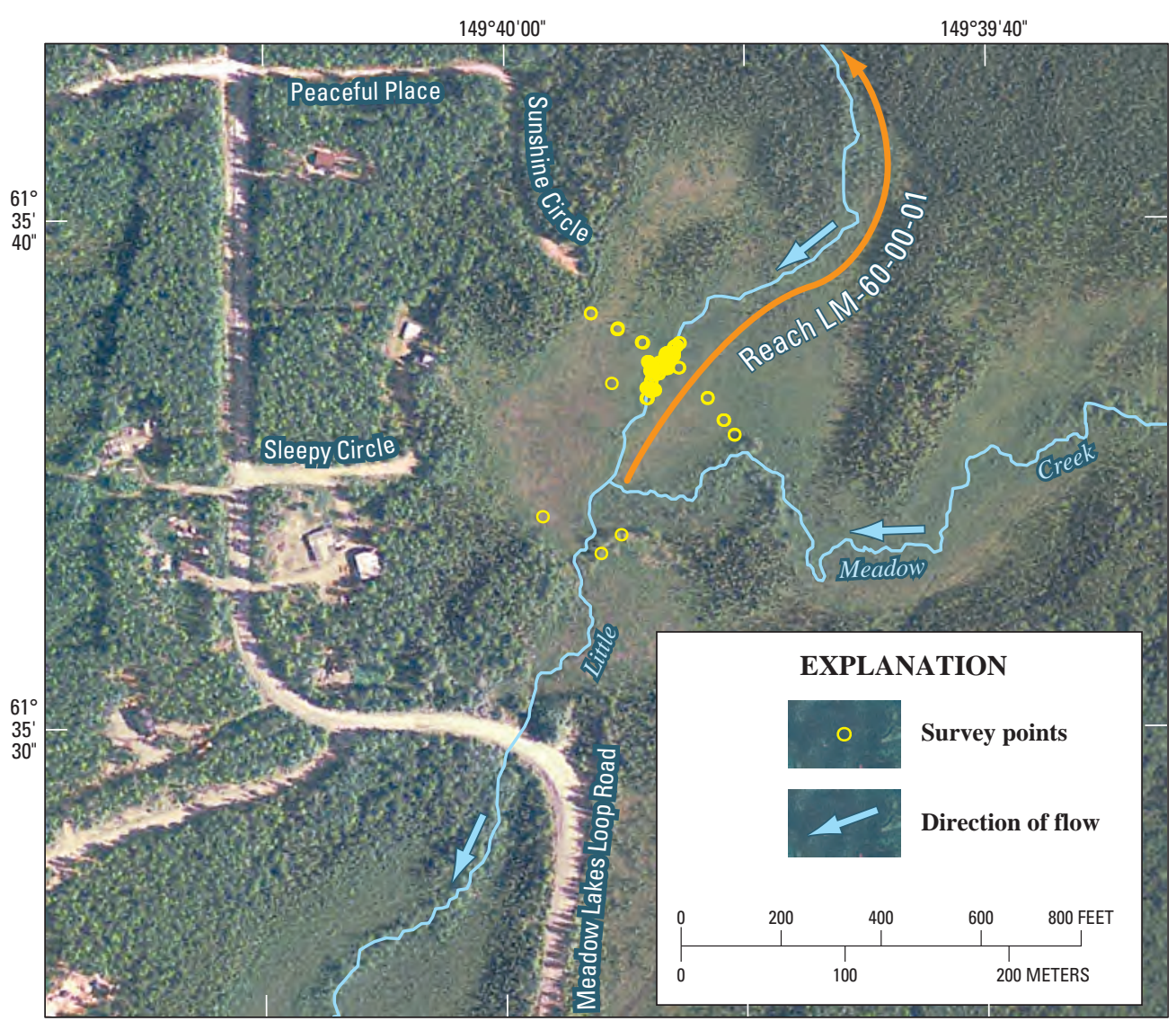

Figure 6. Study reach and survey points on unnamed tributary to Little Meadow Creek, Alaska (reach LM-60-00-01).
The site is a low-gradient reach integrally linked with the flood plain, which is a palustrine emergent wetland (U.S. Fish and Wildlife Service, 2007) and covered with standing or slow-moving water for most of the year. A low, sinuous ridge downstream from the site and extensive peat deposits in the channel bed and banks indicate that the area might once have been a pond, perhaps formed by past beaver activity. Swift flow is conveyed by the channel and slower flows are conveyed by the surrounding wetland. Visual observations of water levels at or above the channel banks during winter and summer 2005 indicate that ground water is a strong component of flow. Channel geometry and habitat attributes for this reach, LM-60-0001 , are discussed below and presented in detail in appendix A. 
Channel Geometry.-This small stream has a narrow and deep active channel (width/depth ratio of 3.1) with a slope of 0.0078 that forms a trench near the center of a broad wetland flood plain (table 4). Bankfull channel width was $5.0 \mathrm{ft}$ and mean bankfull depth was $1.6 \mathrm{ft}$, with a sinuosity of 1.4 (table 4). The top of the channel banks are poorly defined and are continuous with the surrounding wetland, such that main channel flow interfingers with the flood plain laterally over a severalfoot-wide margin (fig. 7). For much of the year, slow-moving water or standing water is present throughout the wetland and near the channel, respectively. The wetland vegetation consists of tussocks with a relief of $1 \mathrm{ft}$ or more, which serve to slow flow velocities on the flood plain.

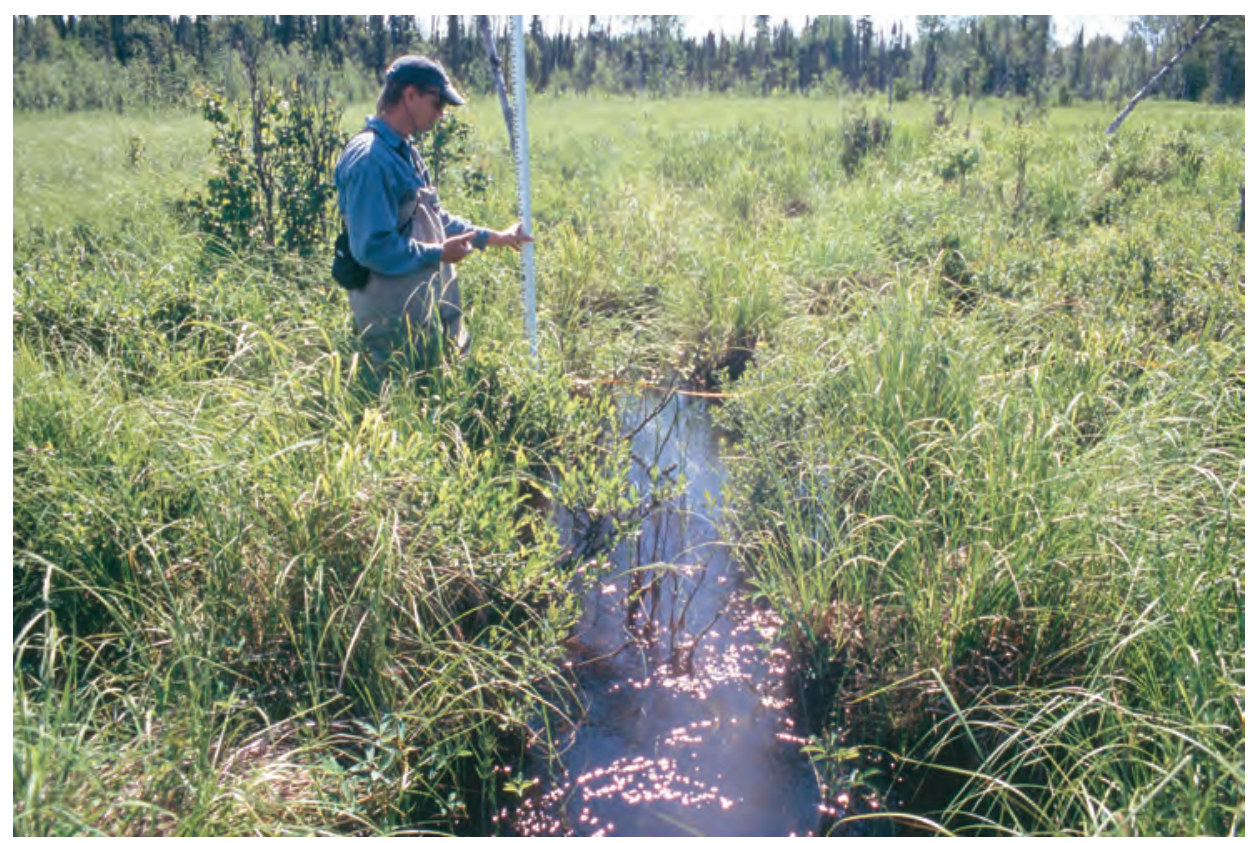

Figure 7. Study reach on unnamed tributary to Little Meadow Creek, Alaska (reach LM-60-00-01).

H abitat.-This tributary is a typical small stream within a peat-wetland complex. The reach is composed entirely of runs, with 50 percent total coverage of habitat cover types, mainly consisting of overhanging vegetation (37 percent), undercut (10 percent), and instream vegetation. No spawning gravels, off-channel habitat, or pools were present. The bed and banks were composed of peat, silt, and sand. Total canopy cover was less than 10 percent and the surrounding wetland type was palustrine emergent, with a water surface connected to the channel over the observation period of summer 2005.

\section{Meadow Creek below Beaver Lake Road}

Meadow Creek is a moderately sized stream at the downstream end of the Big Lake drainage that flows into the northeastern corner of Big Lake. The study site on Meadow Creek is about 1.0 stream mile downstream of South Beaver Lake Road and 2.4 stream miles upstream of Big Lake. As in the Little Meadow Creek tributary reach, this reach of Meadow Creek is connected integrally to its palustrine emergent wetland flood plain, which was inundated to the level of the stream during site visits in summer 2005 (figs. 8 and $\underline{9}$ ). The sandy channel bed is populated with aquatic macrophytes. The channel is navigable by boat from Big Lake to the South Beaver Lake Road culvert upstream from the study site. Channel geometry and habitat attributes for this reach, MDO-00-04, are discussed below and presented in detail in appendix A.
Channel G eometry.--Meadow Creek maintains a lowgradient, meandering channel throughout the study reach and surrounding areas, with a slope of 0.001 and sinuosity of 2.3. Bankfull channel width was $26 \mathrm{ft}$ and mean bankfull depth was $3.2 \mathrm{ft}$. The active channel, which has a width/ depth ratio of 8.1, is slightly entrenched into the wetland flood plain (fig. 9). Tussocks, bushes, and small trees within the flood plain create relief of 1-3 ft across the wetland, which is continuous with the top of the poorly defined channel banks. Like the unnamed tributary to Little Meadow Creek, the Meadow Creek channel maintains an active channel through a broad peatland, but it is wider and deeper, less entrenched, about 60 percent more sinuous, and has a width/depth ratio about 3 times higher.

Habitat.-This reach was typical of Meadow Creek and was composed of about 75 percent run and 25 percent pool features. The site had about 70 percent total coverage of habitat cover types, consisting mainly of instream vegetation. Only two pieces of woody debris were noted along the 600-ft reach. No spawning gravels or off-channel habitat were present. The bed and banks were composed of peat, silt, and sand. Total canopy cover was less then 10 percent and the surrounding wetland type was palustrine emergent (U.S. Fish and Wildlife Service, 2007), with a water surface connected to the channel over the observation period of summer 2005. 


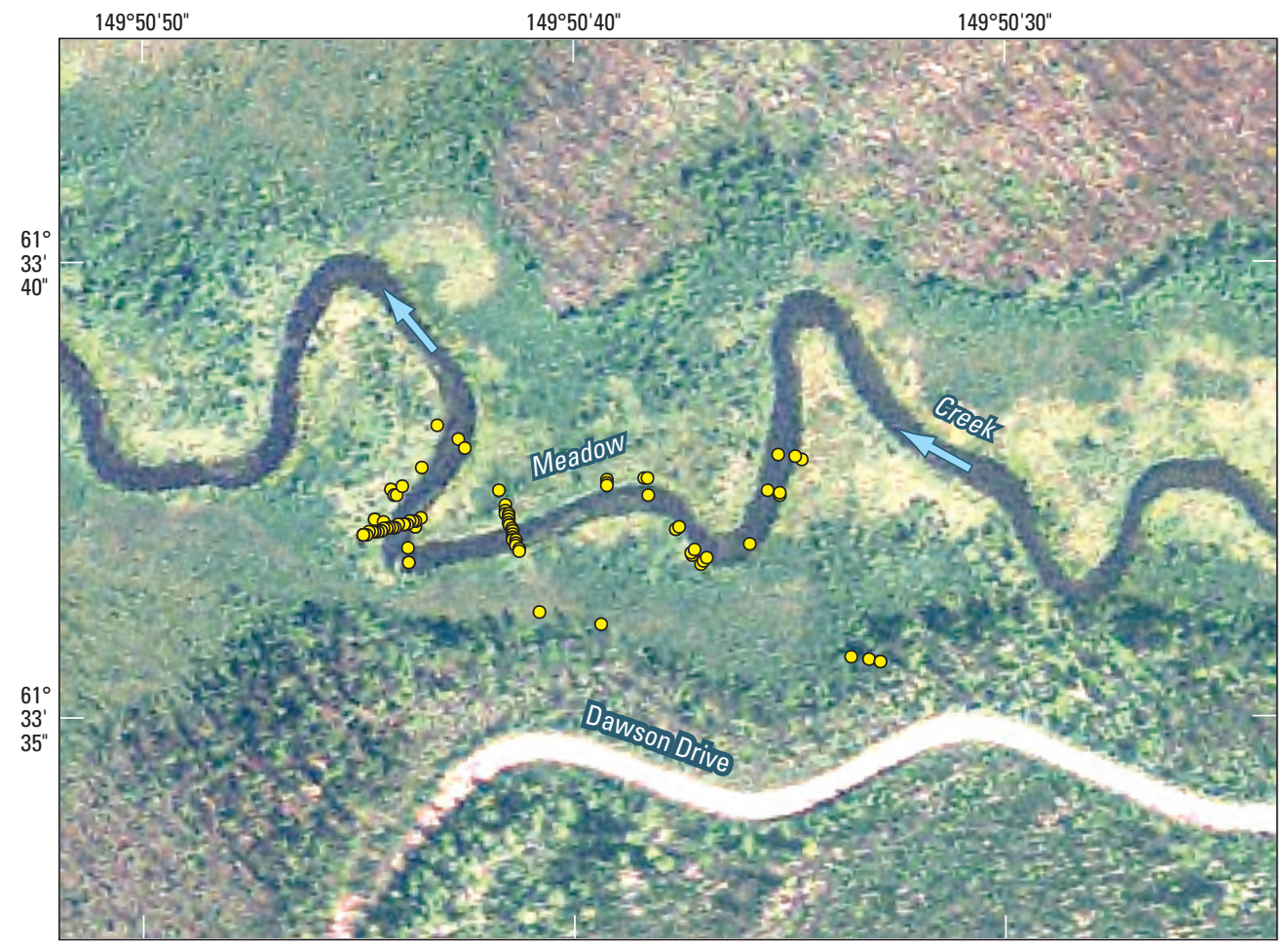

Figure 8. Study site and survey points on Meadow Creek, Alaska (reach MD0-00-04).
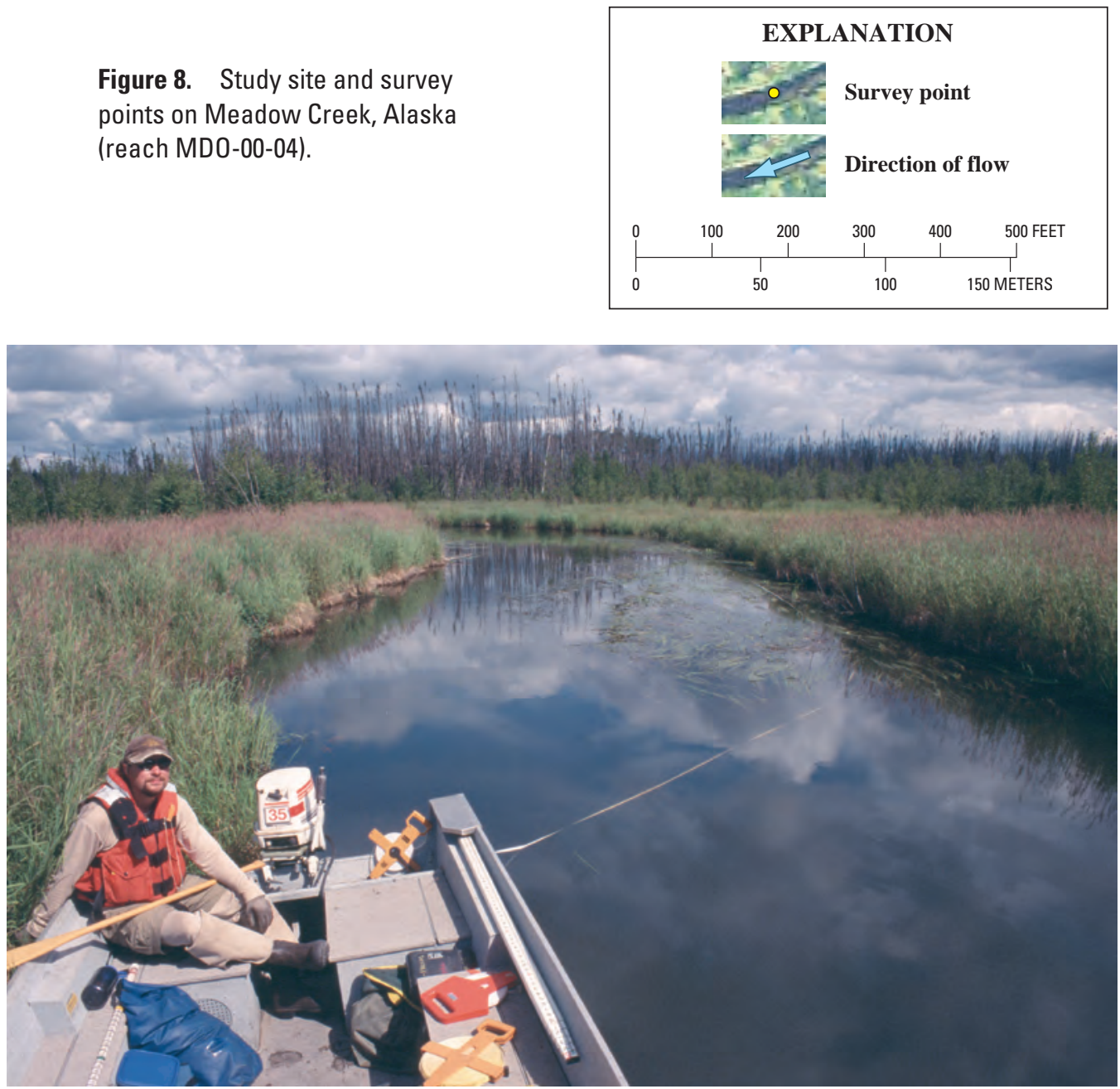

Figure 9. Study site on Meadow Creek, Alaska (reach MD0-00-04). 


\section{Systematic Assessment of Meadow and Little Meadow Creeks}

Channel Geometry.- Reach-length-weighted summary statistics for all study reaches combined, for Meadow Creek, and for Little Meadow Creek are listed in table 5 that describe variations along the stream network. Little Meadow Creek typically was wider relative to its depth than Meadow Creek (width/depth ratios of 14 versus 11, respectfully) and had a steeper weighted average stream gradient $(0.71$ percent versus 0.15 percent). Field observations noted a series of changes in gradient along Little Meadow Creek, in which the stream flows through wide-wetland areas with little slope, and then flows through a higher gradient, cobbly reach to the next flat area. Channel attributes in this area seem to be related to landforms influenced by glaciers and, more recently, beaver activities. Meadow Creek mainly has peat, silt, and sand banks and a sandy streambed, whereas Little Meadow Creek has an assortment of peat, gravel, and cobble streambeds with peaty or cobbly banks, depending on the reach. Data by reach are included in appendix A.

Bankfull width, width/depth ratio, and entrenchment ratio for Little Meadow and Meadow Creeks indicate variations with distance upstream (fig. 10). Bankfull width is noticeably wider from Big Lake to the Parks Highway than in upstream reaches. Width/depth ratios do not indicate a trend with distance upstream, but are more variable along Little Meadow Creek than Meadow Creek. Entrenchment ratios also did not indicate a trend with distance upstream, but variability increased upstream from Meadow Lakes Loop.
Habitat.-Habitat assessments showed that the systematically assessed reaches provide excellent rearing habitat for trout, anadromous and resident fish, but more limited spawning habitat for trout and salmonids. Figures 11 and 12 show percent of habitat types present and the types of dominant habitat cover prevalent along the stream reaches, respectively. Most of the creeks have run types of habitats, which are neither pools nor riffles. Meadow Creek has no riffle features, but has a similar amount of pool features as a function of wetted area as Little Meadow Creek.

Within the systematically assessed reaches, about onehalf of the wetted channel area is composed of some kind of habitat cover type. Instream vegetation was the most common dominant cover type, followed by overhanging vegetation. Overhead canopy cover comprised less than 10 percent for most of the reaches. Some off-channel habitat was present in some reaches, but was not a common feature. Woody debris did not constitute a dominant habitat type.

Spawning gravels for salmonids or trout were present in some reaches, with some intermittent areas throughout the assessed reaches and some whole reaches in Little Meadow Creek (fig. 13). In general, about 40 percent of the length of Meadow Creek and 26 percent of the length of Little Meadow Creek had some limited presence. In addition, Little Meadow Creek had whole reaches composed of spawning gravels, which amounted to about 29 percent of its stream length.

Adjacent riparian area in the assessed reaches consisted of three types: shrub/herb, deciduous forested, or mixed conifer/deciduous forested. Almost all stream reaches were in riparian wetland areas, which were identified as three wetland types: palustrine emergent, shrub/scrub and forested wetlands (fig. 14).

Table 5. Average channel attributes for Meadow Creek and Little Meadow Creek reaches, Alaska, weighted by reach length.

[Ranges of attributes shown in parentheses. Width/depth ratio and E ntrenchment ratio: Ratios were computed prior to rounding and may not match the result obtained by dividing other, rounded values in this table. ft, feet]

\begin{tabular}{lccccc}
\hline \multicolumn{1}{c}{ Stream } & $\begin{array}{c}\text { Bankfull } \\
\text { depth (ft) }\end{array}$ & $\begin{array}{c}\text { Bankfull } \\
\text { width (ft) }\end{array}$ & $\begin{array}{c}\text { Width/depth } \\
\text { ratio }\end{array}$ & \multicolumn{2}{c}{$\begin{array}{c}\text { Entrenchment } \\
\text { ratio }\end{array}$} \\
\hline $\begin{array}{l}\text { Meadow and Little Meadow Creek } \\
\text { reaches, combined }\end{array}$ & 2.4 & 23 & 12 & 26 & 0.0048 \\
Meadow Creek reaches & $(0.20-4.6)$ & $(4.2-49)$ & $(2.6-82)$ & $(1.3-150)$ & $(0.0001-0.029)$ \\
& 3.4 & 32 & $(26-49)$ & $(8.7-24)$ & 0.002 \\
Little Meadow Creek reaches & $(2.0-4.6)$ & 17 & 14 & $(7.8-30)$ & $(0.0001-0.0018)$ \\
& 1.7 & $(4.2-61)$ & $(2.6-83)$ & $(1.3-150)$ & $(0.0001-0.029)$ \\
\hline
\end{tabular}




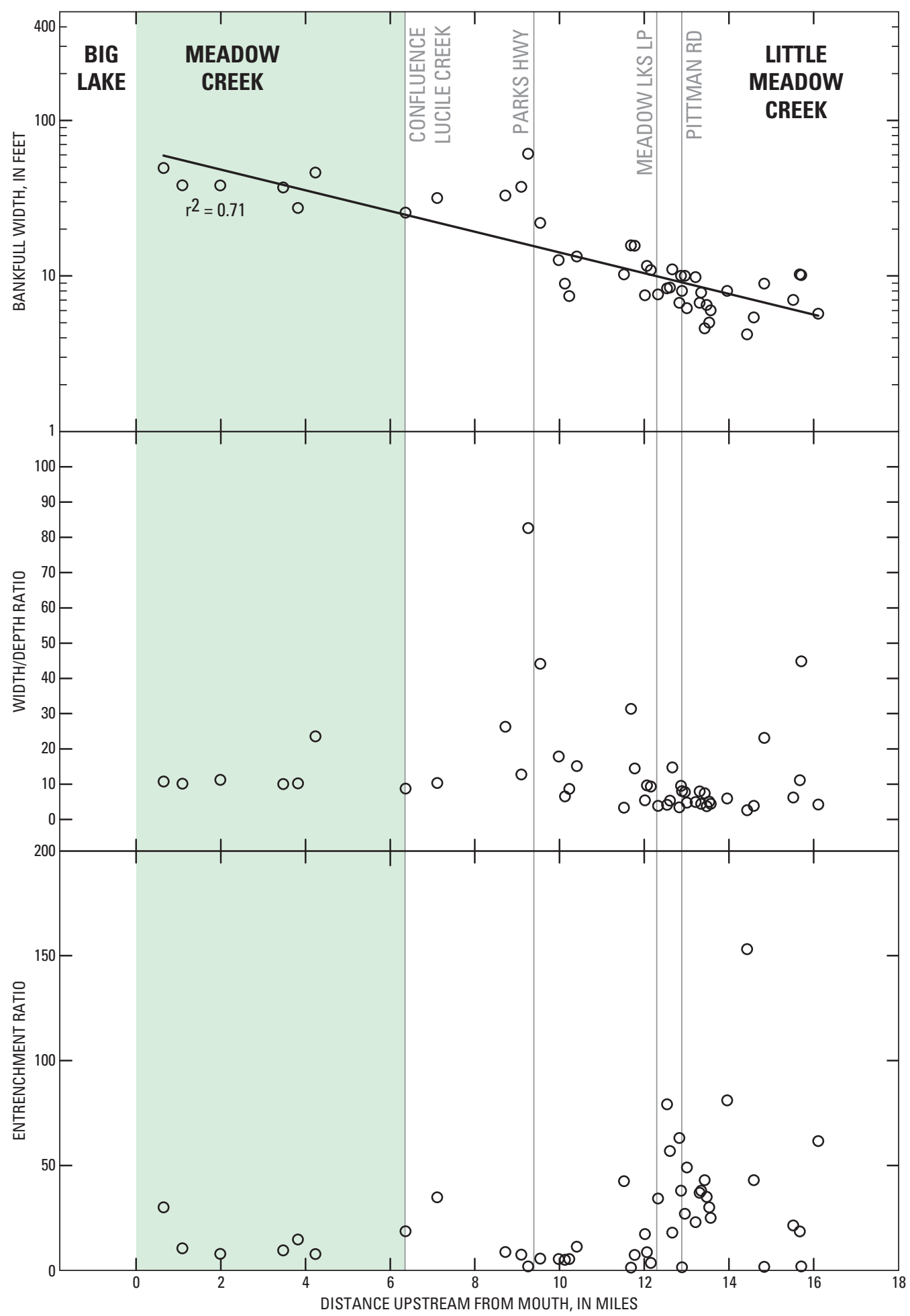

Figure 10. Variation of bankfull channel width, width/depth ratio, and entrenchment ratio with distance along Meadow and Little Meadow Creeks, Alaska. 


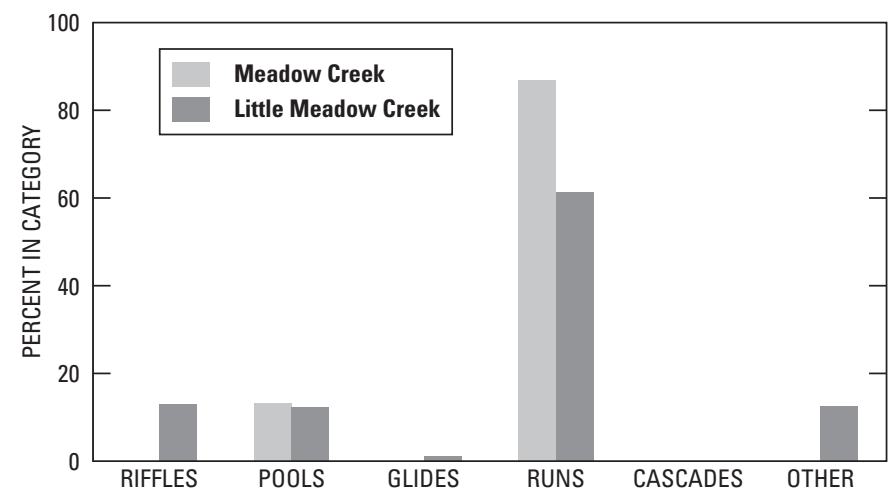

Figure 11. Habitat types as a percent of wetted area for study reaches along Meadow and Little Meadow Creeks, Alaska.

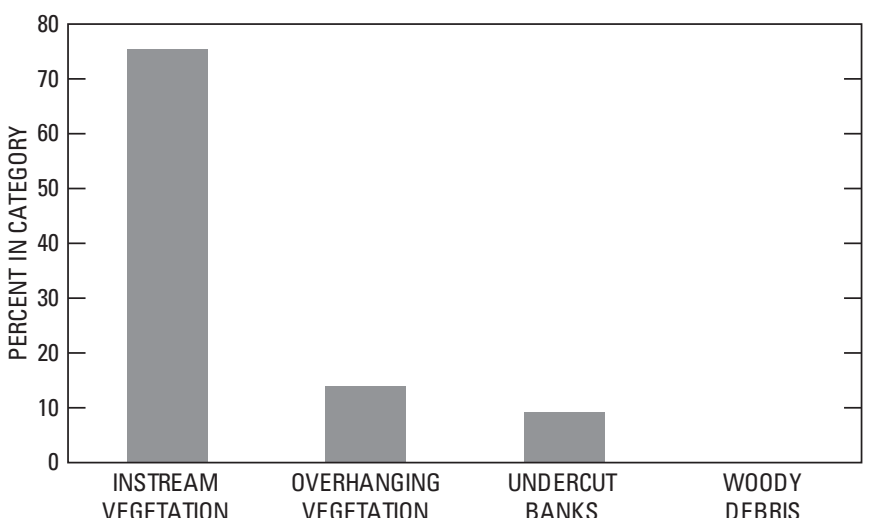

Figure 12. Dominant habitat cover type by percent of total length of stream assessed, Meadow and Little Meadow Creeks, Alaska.

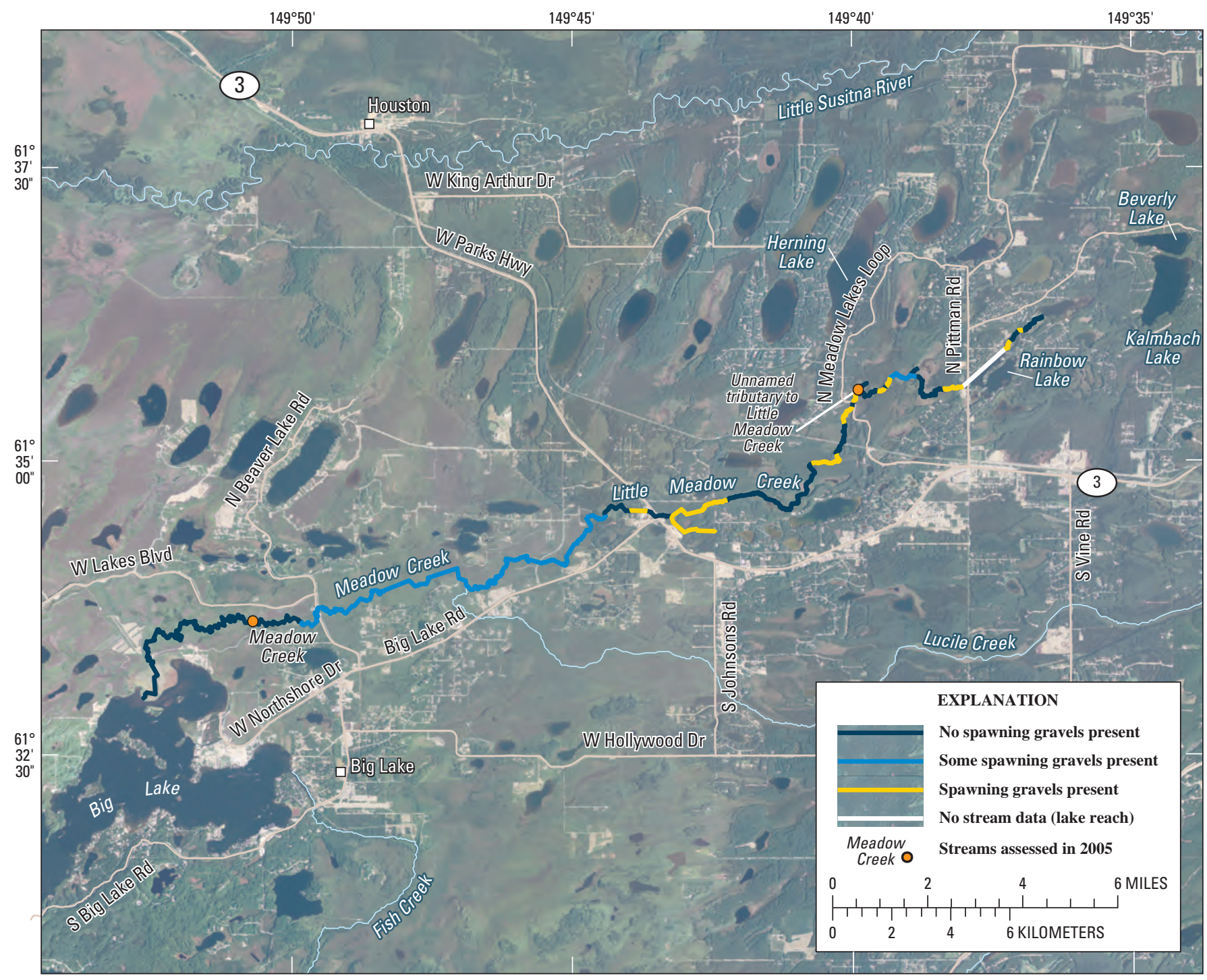

Imagery: USDA-NRCS orthophoto, 1-meter pixels, 2004 photography. Basemap modifed from

USGS digital datasets, various scales. Projection: Albers, CM: -149.5, SP 1: 55.0, SP 2: 65.0, Lat.

Origin: 50.0, False easting: 0, False northing: 0; North American Datum 1927

Figure 13. Locations where spawning-sized gravel is present, or where some spawning gravel is present, along Meadow and Little Meadow Creeks, Alaska. 


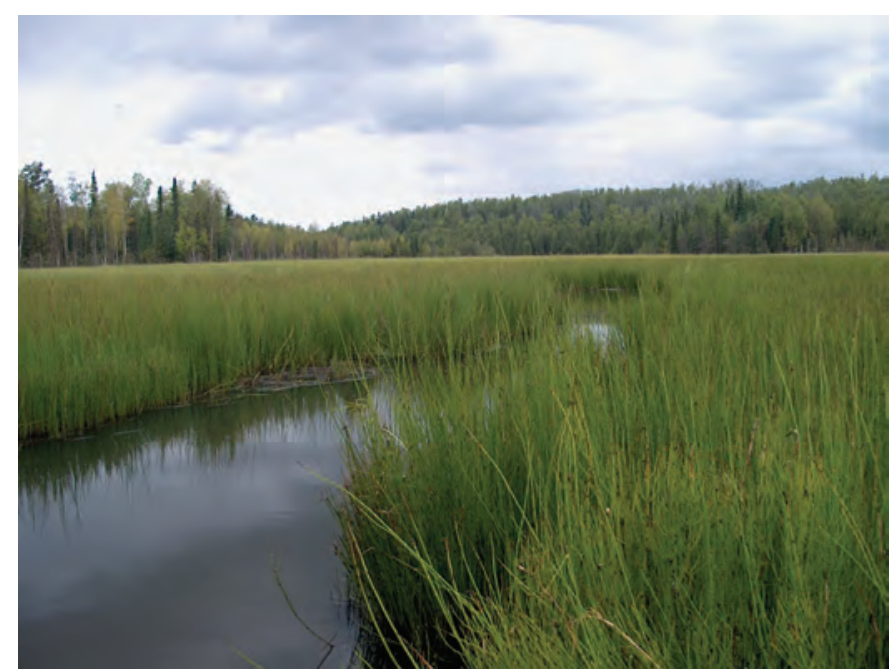

Emergent

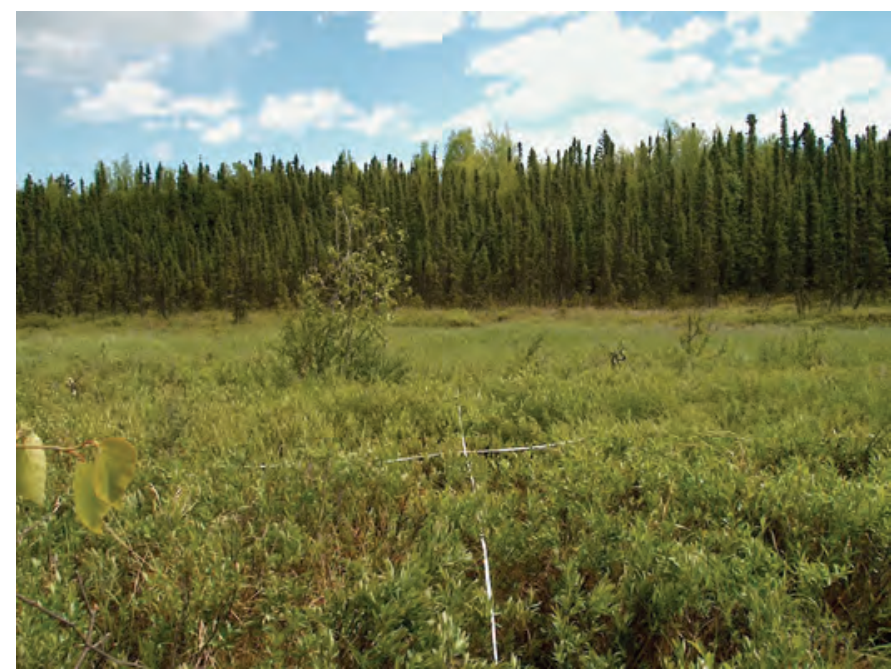

Shrub-scrub

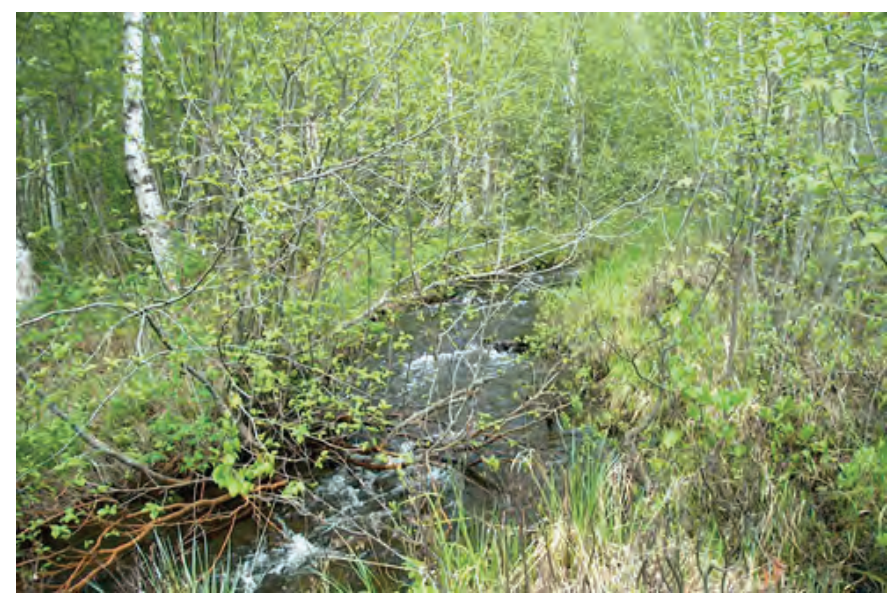

Forested

Figure 14. Examples of palustrine emergent, shrub-scrub, and forested wetlands associated with stream reaches along Meadow and Little Meadow Creeks, Alaska.

\section{Implications for Stream Assessment in the Matanuska-Susitna Valley}

This limited assessment of Mat-Su Valley streams provided data that may be used as a reference for modeling and restoration activities and highlighted gaps in understanding local stream processes. Additional geomorphic and habitat data needed to complete a stream assessment in the Mat-Su Valley are hydrologic data, relative influence of surface water and ground water, and local geologic materials and geomorphic landforms. Other useful analyses include baseline water quality, biotic community parameters, and fish distribution and usage data.

A fundamental question with underlying management implications is the source of the water in the streams and the role of water source in determining streams' physical and habitat attributes. From inspection of regional hydrography, ground water appears to be a strong component of streamflow in some areas, particularly within the Big Lake drainage basin (the Meadow/Little Meadow Creek network). However, the source waters for small streams and their viability over time in the face of increasing water withdrawals and climate change, as well as potential water-quality impacts, are poorly understood. The ability of lower-gradient, ground-water fed streams to modify their beds and banks at annual to multiannual flows also are not as well understood as for typical alluvial streams.

Water-quality data would contribute to the analysis of small streams in this area. Field parameters including temperature, $\mathrm{pH}$, dissolved oxygen, and specific conductance generally provide an indication of habitat quality. Selected parameters also may be useful for determining water source, in that some streams may have characteristics inherited from their lake sources or from local ground-water upwellings. Baseline monitoring of water quality in small streams would provide a metric for the impact of urbanization.

The lateral extent of the flood plain became a useful tool for distinguishing between groups of streams and highlighted the lack of understanding of wetland areas. The presence of broad wetland flood plains may be an important variable in the evolution and maintenance of local small streams. Similarly, the function and dynamics of riparian or aquatic vegetation has not been examined; data regarding the extent and seasonal/ annual variations in aquatic macrophytes, for example, would provide a useful assessment of dynamic habitat conditions and cyclical fluctuations.

Additional drainage basin and reach-scale landscape data needed include physical attributes such as gradient and confinement and geologic and geomorphic considerations like the underlying geologic materials and the presence of terraces or glacial landforms. The presence of coarse glacial deposits or silty lacustrine deposits, for instance, may influence 
channel morphology and hydrology. Similarly, studies of fish distribution and habitat use may help stratify the streams. The importance of various stream types to the productivity and health of the Cook Inlet fishery as well as local resident fish populations has not been explored.

\section{Summary}

A cooperative study by the U.S. Geological Survey and the U.S. Fish and Wildlife Service in 2005 collected fieldbased channel geomorphic and habitat data as a baseline and as an initial effort toward understanding the distribution and function of small streams in the Matanuska-Susitna Valley (Mat-Su) Valley. To provide a reference for other studies and restoration activities, three streams were selected as representative of a subset of the major stream types in the Mat-Su Valley. For a systematic inventory of several streams within a single drainage, stream courses were first delineated for the entire Big Lake drainage from maps, aerial photographs, and site visits. Meadow Creek and one of its major tributaries, Little Meadow Creek, were then selected for the systematic inventory and 55 reaches were identified on the basis of physical and habitat parameters, primarily gradient, substrate, and vegetation. Channel geometry and aquatic habitat data were collected at the three stream reaches strategically selected to be representative of Mat-Su Valley streams and also were systematically collected on the Meadow and Little Meadow Creek reaches. Drainage basin scale data including drainage area, precipitation, and percentage of lakes and ponds, were determined for the three representative reaches.

The sites selected for the representative stream assessment included a tributary to the Little Susitna River, selected to represent steep streams draining the sideslopes of the Talkeetna Mountains. The assessed site had a limited floodplain and a gravelly, pool-riffle-glide structure. The other two sites, a tributary to Little Meadow Creek, and Meadow Creek, represent small and large examples of a peatland stream in a ground-water-dominated basin, respectively. Measurements along selected representative reaches show that gradients, channel width and depth, connectivity with flood plains, and habitat vary among various types of streams.

The systematic assessment of 55 stream reaches along Meadow Creek and its tributary Little Meadow Creek provided statistics on changes in channel geometry and habitat associated with distance along the stream. Width/depth and entrenchment ratios did not show a strong trend with distance, but channel width increased downstream as expected in a log-linear manner. Reasons for local variations in width/depth and entrenchment ratios in the uppermost areas of the drainge (along Little Meadow Creek) are not well understood. Habitat types along most reaches consisted of runs. Habitat cover was present over about 53 percent of the wetted channel area, and consisted primarily of instream vegetation. Gravel suitable for spawning was present in limited areas along Meadow Creek, and along about 29 percent of the length of Little Meadow Creek. Most reaches along both streams flowed through wetlands, including palustrine emergent, shrub/scrub, and forested wetlands.

Data collected for this report led to an assessment of the information needs for analysis of small streams in the Mat-Su Borough. Additional information needed to understand stream functions and sensitivity to natural and human-induced changes include hydrologic, geologic and geomorphic, and biologic data. Hydrologic information needs include streamflow data, water-quality data, and the relative contribution of ground water and surface water. The influence of surficial geology and glacial landforms may correlate to channel morphology and geomorphic sensitivity to change and is relatively unexplored in the area. Biologic indicators such as algae and macroinvertebrates would provide an important baseline and assessment of stream ecology, and documentation of fish distribution and usage of various reaches would help prioritize the relative importance of various stream types. Analyses that will be critical as multiple agencies work to understand small streams in this rapidly developing area include the correlation between streamflow, surficial geology, glacial landforms, drainage modifications by beavers and humans, and channel geometry and habitat characteristics. Additional mapping of small streams and a more comprehensive stream assessment as these analyses are completed will improve understanding of small stream networks.

\section{References Cited}

Alaska Department of Commerce, Community, and Economic Development, 2005, Alaska community database community summaries (CIS): Alaska Department of Commerce. Available at URL: http://www.commerce.state. ak.us/dca/commdb/CIS.cfm

Barnes, F.F., 1962, Geologic Map of the Lower Matanuska Valley, Alaska: U.S. Geological Survey Miscellaneous Geological Investigations Map I-359.

Barnes, J., 1997, Matanuska Valley Road and Recreation Map, Southcentral Alaska: Anchorage, AK, Todd Communications, scale 1:63,360.

Curran, J.H., Meyer, D.F., and Tasker, G.D., 2003, Estimating the magnitude and frequency of peak streamflows for ungaged sites on streams in Alaska and conterminous basins in Canada: U.S. Geological Survey Water-Resources Investigations Report 03-4188, 101 p. Available at URL: http://pubs.usgs.gov/wri/wri034188/ 
Fitzpatrick, F.A., Waite, I.R., D. Arconte, P.J., Meador, M.R., Maupin, M.A., and Gurtz, M.E., 1998, Revised methods for characterizing stream habitat in the National Water-Quality Assessment Program: U.S. Geological Survey WaterResources Investigations Report 98-4052, 67 p.

Freethey, G.W., and Scully, D.R., 1980, Water resources of the Cook Inlet basin, Alaska: U.S. Geological Survey Hydrologic Investigations Atlas HA-620, 4 sheets, scale 1:1,000,000.

Haeussler, P.J., 1998, Surficial Geologic Map along the Castle Mountain Fault Between Houston and Hatcher Pass Road, Alaska: U.S. Geological Survey Open-File Report 98-480.

Hogan, E.V., 1995, Overview of environmental and hydrogeologic conditions near Big Lake, Alaska: U.S. Geological Survey Open-File Report 95-403, 59 p.

Johnston, N.T., and Slaney, P.A., 1996, Fish habitat assessment procedures: Province of British Columbia, Canada, Watershed Restoration Program, Ministry of Environment, Lands, and Parks, and Ministry of Forests, Watershed Restoration Technical Circular no. 8, 97 p.

Jokela, J.B., Munter, J.A., and Evans, J.G., 1991, Groundwater resources of the Palmer-Big Lake area, Alaska: A conceptual model: Alaska Department of Natural Resources Division of Geological and Geophysical Surveys Report of Investigations 90-4, 38 p., 3 sheets, scale 1:25,000.

Jones, S.H., and Fahl, C.B., 1994, Magnitude and frequency of floods in Alaska and conterminous basins of Canada: U.S. Geological Survey Water-Resources Investigations Report 93-4179, 122 p.

Matanuska-Susitna Borough, 2005, Big Lake watershed forum, citizen and agency concerns and recommendations for the watershed: Matanuska-Susitna Borough Planning and Land Use Department, 121 p.

Plafker, G., 1969, Tectonics of the March 27, 1964, Alaska earthquake: U.S. Geological Survey Professional Paper 543-I.

Reger, R.D., Pinney, D.S., Burke, R.M., and Wiltse, M.A., 1996, Catalog and initial analyses of geologic data related to Middle to Late Quaternary deposits, Cook Inlet region, Alaska: Alaska Division of Geological and Geophysical Surveys Report of Investigation 95-6.
Reger, R.D., and Updike, R.G., 1983, Upper Cook Inlet Region and the Matanuska Valley, in Pewe, T.L., and Reger, R.D., eds., Guidebook to Permafrost and Quaternary Geology along the Richardson and Glenn Highways between Fairbanks and Anchorage, Alaska: Guidebook 1: Alaska Division of Geological and Geophysical Surveys, Fairbanks, Alaska, p. 185-259.

Rosgen, D.L., 1996, Applied river morphology: Pagosa Springs, CO, Wildland Hydrology, variously paged.

Trainer, F.W., 1960, Geology and ground-water resources of the Matanuska Valley agricultural area, Alaska: U.S. Geological Survey Water-Supply Paper 1494, 116 p., 3 plates.

Trainer, F.W., 1961, Eolian deposits of the Matanuska Valley Agricultural Area, Alaska: U.S. Geological Survey Bulletin 1121-C, 34 p.

U.S. Department of Agriculture, 1998, Stream corridor restoration: Principles, processes, and practices: U.S. Department of Agriculture Natural Resources Conservation Service, chap. 7, p. 7-34-7-39. Available at URL: http:// www.nrcs.usda.gov/technical/stream restoration/newgra. $\underline{\mathrm{html}}$

U.S. Department of Agriculture Natural Resources Conservation Service, 2005, Matanuska-Susitna Borough: U.S. Department of Agriculture Natural Resources Conservation Service, 1-meter pixel orthoimagery. Contact information is available at URL: http://alaska.usgs.gov/ science/geography/orthoimagery/mat-su.html

U.S. Fish and Wildlife Service, 2004, Matanuska-Susitna Borough culvert survey GIS-based dataset: Product from Agreement no. 701814G274 between U.S. Fish and Wildlife Service Region 7 and Matanuska-Susitna Borough Department of Public Works. Available as part of interactive mapper at URL: http://www.sf.adfg.state.ak.us/SARR/ Fishpassage/FP mapping.cfm

U.S. Fish and Wildlife Service, 2007, Wetlands Mapper: U.S. Fish and Wildlife Services. Available at URL: http://www. fws.gov/wetlands/data/index.html

Wheaton, S.R., 2003, Municipality of Anchorage hydrography data dictionary: Municipality of Anchorage Watershed Management Program, Project no. 95001, 64 p.

Winkler, G.R., 1992, Geologic Map and Summary Geochronology of the Anchorage $1^{\circ} \times 3^{\circ}$ Quadrangle, Southern Alaska: U.S. Geological Survey Miscellaneous Investigations Series Map I-2283. 


\section{Appendix A. Study Reach Data.}

The appendix data files, stored in Microsoft Excel, and the shapefile presenting the reaches and their characteristics are available for download at http://pubs.usgs.gov/sir/2009/5084/. 
This page intentionally left blank. 
Publishing support provided by the U.S. Geological Survey Publishing Network, Tacoma Publishing Service Center

For more information concerning the research in this report, contact the Director, Alaska Science Center

U.S. Geological Survey

4210 University Drive

Anchorage, Alaska 99508

http://alaska.usgs.gov 
